\title{
Zn-Pb Mineralization Associated with Salt Diapirs in the Basque-Cantabrian Basin, Northern Spain: Geology, Geochemistry, and Genetic Model
}

\author{
Joaquim Perona, ${ }^{1}$ Àngels Canals,,${ }^{2, \dagger}$ and Esteve Cardellach ${ }^{3}$ \\ ${ }^{1}$ Centres Científics i Tecnològics, Universitat de Barcelona, 08028 Barcelona, Spain \\ ${ }^{2}$ Departament de Mineralogia, Petrologia i Geologia Aplicada, Facultat de Ciències de la Terra, \\ Universitat de Barcelona, 08028 Barcelona, Spain \\ ${ }^{3}$ Departament de Geologia, Facultat de Ciències, Universitat Autònoma de Barcelona, 08193 Cerdanyola del Vallès, Spain
}

\begin{abstract}
Vein and stratabound $\mathrm{Zn}-\mathrm{Pb}$ sulfides are hosted within siliciclastic rocks and marine carbonates of Cretaceous age and within caprock carbonates at the margins of the Murguía and Orduña saline diapirs in the BasqueCantabrian basin. Organic matter is ubiquitous, and textures indicate a genetic link to sulfide precipitation. Sulfides (pyrite, sphalerite, and galena) precipitated from brines with halogen ratios compatible with halite dissolution. Thermal indicators (fluid inclusion, organic matter, and sulfur isotope data), point to formation temperatures between $150^{\circ}$ and $200^{\circ} \mathrm{C}$.

The $\delta^{34} \mathrm{~S}$ values of sphalerite and galena (4.1-15.1\%) suggest a sulfur source related to the reduction of evaporite sulfate (thermochemical sulfate reduction) of Triassic age (15.3-17.4\%o). The interaction of carbonpoor, metal- and sulfate-bearing hot brines with host rocks activated the cracking of organic matter, triggering sulfide precipitation at a rate controlled by the $\mathrm{H}_{2} \mathrm{~S}$ production.

Textural relationships suggest that ore precipitation was related to dolomitization of host rocks (siliciclastic rocks, marine carbonates, and caprock). The $\delta^{13} \mathrm{C}$ and $\delta^{18} \mathrm{O}$ of carbonates range from 3.5 to $-20.5 \% 0$ and from 16.1 to $28.7 \%$, respectively, indicative of different carbon sources and host-rock types. Carbonates associated with sulfide mineralization depict $\delta^{13} \mathrm{C} / \delta^{18} \mathrm{O}$ assemblages and ${ }^{87} \mathrm{Sr} / 86 \mathrm{Sr}$ ratios $(0.70801-0.71202)$ resulting from the interaction of a basinal brine with the different host rocks. Galena $\mathrm{Pb}$ isotope ratios- ${ }^{206} \mathrm{~Pb} / 204 \mathrm{~Pb}$ from 18.643 to $18.696,{ }^{207} \mathrm{~Pb} /{ }^{204} \mathrm{~Pb}$ from 15.650 to 15.676 , and ${ }^{208} \mathrm{~Pb} / 204 \mathrm{~Pb}$ from 38.720 to 38.780 -point to metal source rocks similar to other Mississippi Valley-type (MVT) deposits of the Basque-Cantabrian basin.

Sulfide concentrations around the Murguía and Orduña diapirs are not concomitant with caprock formation but with dolomitization, as in MVT deposits. This is in contrast with the diapir-related deposits of the Gulf Coast and shares characteristics with the diapir-related mineralization in North Africa.
\end{abstract}

\section{Introduction}

The relationship between salt diapirs and hydrocarbons is widely known, and these structures have been targets for oil and gas exploration elsewhere (e.g., Grunau, 1987; Harding and Huuse, 2015). An additional economic interest of some salt diapirs is their association with $\mathrm{Zn}-\mathrm{Pb}$ sulfide deposits, especially in North Africa and the Gulf Coast (USA). Moreover, studies and field examinations of some Mississippi Valley-type (MVT) deposits in China and in South and North America suggest that the relationship between ores and evaporites or salt tectonic structures is more common than previously recognized (Leach et al., 2010, 2017; Leach, 2014).

According to Kyle and Price (1986), Posey and Kyle (1988), Kyle and Posey (1991), and Kyle and Saunders (1996), in the Gulf Coast diapirs, sulfide precipitation is related to caprock formation. In contrast, in salt diapir-related ores in North Africa (e.g., Tunisia: Bou Grine, Fedj-el-Adoum) the genesis of the deposits is not related to caprock development (Rouvier et al., 1985; Sheppard et al., 1996; Bouhlel et al., 2016), and fracture systems around the diapiric structures may act as channelways for fluids, extending mineralization into the surrounding rocks. Distinguishing between these two models has exploration implications, because sulfide ores would be constrained not only to areas on top of salt domes but also to favorable rocks surrounding the diapirs.

\footnotetext{
† Corresponding author: e-mail, angelscanals@ub.edu
}

Historically, the Basque-Cantabrian basin (northern Spain) has been an important $\mathrm{Zn}-\mathrm{Pb}$ mining region. It contains numerous MVT Zn-Pb deposits enclosed within dolomitized carbonates of Lower Cretaceous age, including the worldclass Reocín district (60 Mt; 12\% Zn) (Velasco et al., 1994). Small stratabound $\mathrm{Zn}-\mathrm{Pb}$ deposits also occur related to diapirs of Triassic evaporite successions intruding sediments of Mesozoic and Cenozoic age. Two of these diapirs, Murguía and Orduña (Fig. 1), are known to host sulfide mineralization (sphalerite and galena) replacing intruded Cretaceous sandstones and carbonates and a discontinuous carbonate horizon bordering the diapirs. Ore deposits were actively mined from the mid-19 $9^{\text {th }}$ to the mid- $20^{\text {th }}$ centuries but had not been studied in detail; however, their potential economic interest was investigated through geologic, geochemical, and drilling surveys by an Outokumpu Spain-Ente Vasco de Energia (EVE) joint venture between 1997 and 1998. As a result, a resource of $\sim 0.5 \mathrm{Mt} \mathrm{Zn}+\mathrm{Pb}$ was estimated.

The present study describes mineralization around the Murguía and Orduña diapirs in order to identify the key factors leading to the formation of these deposits and to contribute to the discussion on the genetic models and scenarios currently accepted for peridiapiric mineralization. Considering that formation of MVT deposits can be part of dolomitization processes (Merino and Canals, 2011) and that the role of caprock in peridiapiric deposits is still under debate, special attention is devoted to the carbonate formation and 

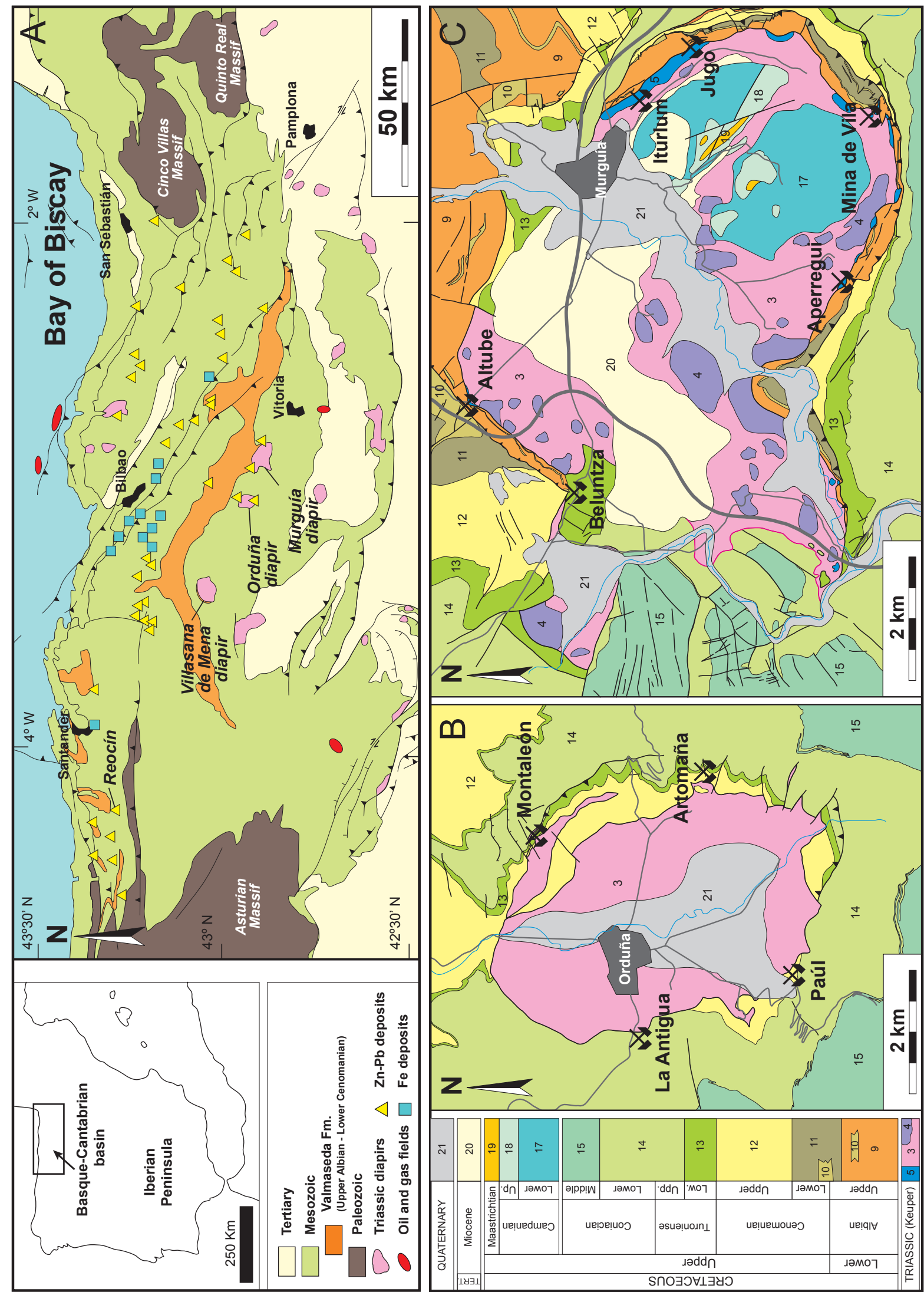

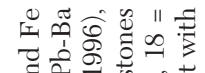

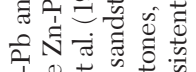
งิ

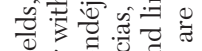

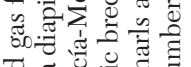

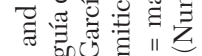

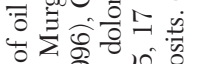
ธิ)

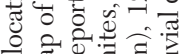

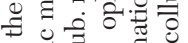
娄然进 ब0讠

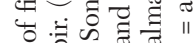
\& $\approx$.

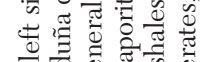

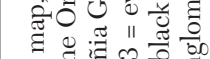

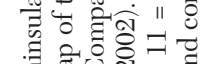
空

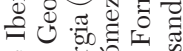

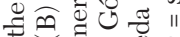

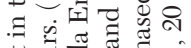

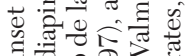

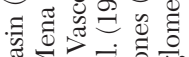
告 䆑

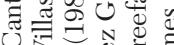

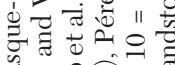
๓

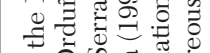
क्षै ह Ð U दे 충 bi 
dolomitization at the contact between the Triassic evaporites and the host Cretaceous sedimentary pile. Our work is based on a detailed field, mineralogical, petrographic, and geochemical (organic matter, stable, and radiogenic isotope) study on samples from outcrops and drill cores.

\section{Geologic Setting and Diapirism}

The Basque-Cantabrian basin is related to rift systems that developed between the European and Iberian plates during the Mesozoic (Salas et al., 2001; Vergès and García Senz, 2001; Taviani and Muñoz, 2012). The Mesozoic stratigraphic record includes sedimentary rocks from the Triassic to the Upper Cretaceous. The Triassic series, deposited during the first rifting stages, is composed of red clastic sediments, platform carbonates, evaporite-rich shales, and ophites. Jurassic rocks typically consist of platform limestones and marls. The intense fault activity during a second rifting event that began in the Late Jurassic led to the deposition of a thick succession of sedimentary rocks, mainly during the Early Cretaceous. The Aptian and Albian sediments may reach up to 7,000 m in the western and central parts of the Basque-Cantabrian basin (García-Mondéjar et al., 2005). This period was characterized by the deposition of shallow-platform limestones with abundant rudist-rich reefs of the Urgonian facies (Rat, 1959). In the central and eastern regions of the Basque-Cantabrian basin, the Urgonian facies are mainly terrigenous, whereas reefal carbonates predominate in the west (García-Mondéjar et al., 1996). Between the Albian and Santonian, the Cretaceous sedimentation was accompanied by submarine alkalinetype volcanism (Castañares et al., 2001). Sediments directly overlying the Urgonian facies are commonly siliciclastic (Utrillas and Valmaseda Formations) and were deposited in continental, delta, and talus environments. Upper Cretaceous and Paleogene rocks range from continental clastics to platform limestones to flysch-type marls.

The Valmaseda Formation (Late Albian to Early Cenomanian; Pérez García et al., 1997), developed in an area of around $1,500 \mathrm{~km}^{2}$ at the southern margin of the basin, extending to the Álava, Vizcaya, and Burgos Provinces (Fig. 1). Its thickness reaches 5,000 m (Ente Vasco de la Energia, 1994) with an average total organic carbon of $1 \%$, constituting a potential unconventional gas source (U.S. Energy Information Administration, 2015).

Sediments of Mesozoic and Cenozoic age are occasionally intruded by evaporite diapirs consisting of Upper Triassic rocks (Keuper facies). Geologic information from outcrops, drill cores, and geophysical surveys shows that the Keuper facies is essentially composed of halite together with red shales, anhydrite, dolostones, and dolerites (Nettelton, 1968; Serrano et al., 1989; Serrano and Martínez del Olmo, 1990). The diapirs are aligned northwest-southeast and northeastsouthwest and are concentrated in the regions surrounding the depocenters of the Aptian-Albian basin (García-Mondéjar et al., 1996; Frankovic et al., 2016, and references therein), which in turn are outlined by the reactivation of basement faults. Examples along the northwest-southeast alignment (Las Losas fault; Martín-Chivelet et al., 2002) are the Murguía, Orduña, and Villasana de Mena diapirs (Fig. 1A).

According to Rat (1988), the diapiric structures were active from at least the Late Cretaceous and were deformed by the Alpine orogeny, which modified their initial morphology; however, the geometry and unconformity of the Cretaceous sediments around the Murguía diapir show that its ascent initiated during Early Cretaceous times, particularly in the Albian when the older recognized halokinetic sequences developed around the Murguía and the neighboring Villasana de Mena diapir (Abalos et al., 2003; E. Roca, unpub. report, 2014). Diapir ascent continued at least up to Santonian times, as attested to by younger halokinetic sequences with reefal deposits. The later evolution is constrained by the existence of Campanian and lower Miocene deposits above the Murguía diapir (López-Horgue and Hernandez, 2003; Barrón et al., 2006), indicating that it did not grow during these times but collapsed, probably by salt dissolution. On the other hand, the lack of contractional structures at the diapir flanks as well as the nearly circular cross-sectional shape of the Murguía, Orduña, and Villasana de Mena diapirs indicate that they were not squeezed during the Alpine compression (Fig. 1).

\section{Samples and Methods}

Ore deposits and occurrences were studied on samples from outcrops and dumps of abandoned mines and on samples from drill cores of the Altube prospect (Murguía diapir) and Paúl deposit (Orduña diapir) (see Fig. 1). In addition, samples from an outcrop at the apparently barren Villasana de Mena diapir were also studied. Transmitted- and reflected-light optical microscopy and cathodoluminescence were used for the petrographic and mineralogical study. Some mineral phases were identified by X-ray diffraction and electron microprobe analysis.

Organic matter microscopic observations were performed with a Leica DMR XP microscope under white (reflected and transmitted) and ultraviolet light. Random reflectivity measurements (reported in \%) were made on polished samples (thin sections and densimetric concentrations), following the procedures of the International Committee for Coal Petrology (1963) and using an oil immersion objective $(50 \times)$. Rock Eval analyses were carried out on a RE6 pyrolyzer (Vinci Technologies), under standard conditions and operating principles described in Lafargue et al. (1998). Hydrogen index, total organic carbon, and temperatures of the maximum rate of hydrocarbon generation $\left(\mathrm{T}_{\max }\right)$ are reported. This study was carried out at the Institut des Sciences de la Terre d'Orléans (ISTO, France).

Sulfides and sulfates were analyzed for their sulfur isotope composition on a Thermo Electron Delta Plus XP isotopic mass ratio spectrometer at Centres Científics i Tecnològics of the University of Barcelona (CCiTUB). After careful separation under a binocular microscope, samples were weighed in a tin capsule, adding $\mathrm{V}_{2} \mathrm{O}_{5}$ as an oxidizing catalyst, and then combusted in a Finnigan elemental analyzer (EA) coupled online with the spectrometer. Sulfide results were calibrated with IAEA S-1, IAEA S-2, IAEA S-3, and NBS-123 and sulfates with NBS-127, IAEA SO-5, and IAEA SO-6 international standards. Results are reported as \%o deviation relative to Vienna-Canyon Diablo Troilite (V-CDT). The analytical precision, based on replicate measurements of the international standards, was $\pm 0.1 \%$.

Oxygen and carbon isotope analyses were performed on ore-stage, host, and regional carbonates (calcite and 
dolomite). Individual crystals were carefully handpicked under a binocular microscope and powdered or, alternatively, drilled with a manual microdrill from polished slabs. Carbonates were analyzed at CCiTUB. About 0.05 to $0.08 \mathrm{mg}$ of sample were reacted at $70^{\circ} \mathrm{C}$ with $100 \%$ phosphoric acid in a Thermo Finnigan Kiel Device III, coupled online with a Thermo Finnigan MAT-252. Results were calibrated with the NBS-18 and NBS-19 international reference materials. Carbon isotopes are reported in \%o deviation relative to Vienna Pee Dee Belemnite (V-PDB) and oxygen isotopes in $\%$ deviation relative to Vienna-standard mean ocean water (V-SMOW). Reproducibility, determined by replicate analysis of standards, was better than $\pm 0.02 \%$ for carbon and $\pm 0.06 \%$ for oxygen.

The Sr isotope composition of carbonates was analyzed at the Centro de Asistencia a la Investigación (CAI) laboratories of the Universidad Complutense de Madrid (Spain). Fifty to $100 \mathrm{mg}$ of sample powder was dissolved in $2.5 \mathrm{~N} \mathrm{HCl}$ at $80^{\circ} \mathrm{C}$, dried and redissolved using $3 \mathrm{M} \mathrm{HNO}_{3}$. The strontium aliquots were extracted using conventional cation exchange procedures, and the ${ }^{87} \mathrm{Sr} /{ }^{86} \mathrm{Sr}$ ratios were analyzed in a TIMSPhoenix thermal ionization mass spectrometer. The reproducibility $(2 \sigma)$ was better than $\pm 0.03 \%$.

The $\mathrm{Pb}$ isotope composition of galenas was analyzed at the Servicio General de Geocronología y Geoquímica Isotópica (Universidad del País Vasco, Spain). Pb was purified with micro/electrodepositional techniques and was converted into a nitrate and dissolved in water to be analyzed in a FinniganMat-262 mass spectrometer equipped with eight Faraday collectors, a device to multiply secondary electrons and NBS-981 as a standard. Samples were loaded onto Re filaments in a mixture of silica gel and phosphoric acid. Precision was better than $\pm 0.01 \%$ for ${ }^{206} \mathrm{~Pb} / 204 \mathrm{~Pb}$ and ${ }^{208} \mathrm{~Pb} / 204 \mathrm{~Pb}$ and better than $\pm 0.03 \%$ for ${ }^{207} \mathrm{~Pb} / 204 \mathrm{~Pb}$.

\section{Diapiric Alteration (Caprock)}

Crestal caprock deposits result from halite dissolution at the top of salt diapirs. They consist of a lithological sequence with an upper calcite zone, an intermediate zone with gypsum, and a lower zone with anhydrite overlying halite (Posey et al., 1987; Posey and Kyle, 1988). Its formation involves fluid circulation, bacterial activity, and organic matter. During crestal caprock development, sour gas deposits can be produced and can act as a source either of sulfate reductants $\left(\mathrm{CH}_{4}\right)$ and/or of $\mathrm{H}_{2} \mathrm{~S}$ for sulfide precipitation. Anhydrite lateral caprocks are also known to occur as sheaths around the diapirs, although their genesis is still a matter of debate (Jackson and Lewis, 2012).

At the Murguía diapir, brecciated carbonate rocks discontinuously crop out at the contact between the Triassic evaporites and the Cretaceous sedimentary pile (see Fig. 1; e.g., Jugo, Aperregui). These were interpreted either as enclaves of Jurassic-age dolostone dragged during piercement (Ente Vasco de la Energia, 1994) or as false caprock (Ábalos et al., 2003). At Altube, this lithology was intersected by drill cores reaching $280 \mathrm{~m}$ below the surface. It consists of a brecciated carbonate horizon (up to $20 \mathrm{~m}$ thick) and minor zebra rocks at the contact between the Valmaseda Formation and the diapir. This carbonate horizon, named "carbonate transition zone," consists of a greenish-colored clast- or matrix-supported heterometric breccia, composed of idiomorphic crystals of zoned dolomite (Fig. 2A), calcite replacing dolomite, phyllosilicates (chlorite, illite-smectite, dickite, nacrite), and minor albite and tourmaline. Bipyramidal millimeter-size quartz crystals with anhydrite inclusions are also present. Pyrite appears disseminated, as idiomorphic to subidiomorphic crystals (up to $1 \mathrm{~mm}$ ) associated with organic matter and phyllosilicates and platy-like crystals (Fig. 2B) probably related to a replacement of a previously existing mineral (sulfates, marcasite [?]). Tourmalines present green cores and noncolored rims (Fig. 2C). In the Al-Fe-Mg diagram (Henry and Gidotti, 1985), the green cores plot within the metapelite and granitoid field tourmalines, whereas the noncolored overgrowths fall within the metaevaporite field (Fig. 3).

As a whole, the carbonate transition zone can be considered a possible remainder of an original caprock. Interestingly, ore grades have been recognized in four boreholes intersecting this carbonate zone (see Fig. 4). Due to their similar macroscopic textures and carbon isotopic signatures (see "Stable Isotope Data" section), carbonate outcrops at Jugo and Aperregui distributed along the diapiric contact have been attributed to the carbonate transition zone described at Altube.

At Orduña, a brecciated horizon that was crosscut during oil exploration drilling performed from the mid-1950s to 1960s was also interpreted as a caprock by Serrano and Martínez del Olmo (1990). In addition, sour gas pockets were found near the contact between this caprock and the evaporites (Baquedano, 2007).

\section{Ore Deposits}

Zinc-lead deposits around the diapirs occur as replacements and veinlets in sandstones of Albian age (Altube: Murguía diapir), in carbonate rocks of Upper Cenomanian to Lower Turonian age (Montaleón, La Antigua, Artomaña: Orduña diapir; Beluntza: Murguía diapir), and within the carbonate transition zone at Aperregui, Mina de Vila, Iturlum, Jugo, and Altube (Murguía diapir).

Sandstone-hosted mineralization consists of $\mathrm{Zn}-\mathrm{Pb}-\mathrm{Fe}$ sulfides replacing microconglomerates, sandstones, and carbonate beds of the Valmaseda Formation. Although at Villasana de Mena diapir, local occurrences of sphalerite, barite, kaolinite, and bitumen were also recognized, the most outstanding example is Altube, located at the northeast margin of the Murguía diapir (see Fig. 1). The following description is based on field observations and the study of nine drill cores, distributed in a 500- $\times 1,200-\mathrm{m}$ area, reaching $365 \mathrm{~m}$ in depth (Fig. 4).

Sandstones of the Valmaseda Formation are made up of monocrystalline quartz (60-95\%), feldspars (5-35\%), rock fragments, muscovite, tourmaline, zircon, and apatite. These rocks show syntaxial quartz and poikilotopic carbonate cements. When sulfides are present, feldspar components are altered to phyllosilicates. Carbonate beds consist of sandy limestones with abundant Orbitolina and bivalves. Amorphous organic matter and bitumen are present in all these rock units (see "Organic Matter Characterization" section).

Mineralization is replacive and consists of centimeter- to 1.5-m-thick disseminated to massive (up to $30 \% \mathrm{Zn}$ ) stratabound lenses, with $500 \mathrm{~m}$ of maximum lateral extent. Sulfides replace the carbonate matrix and the silicic lithoclasts of the sandstones (Fig. 2E, F). Lens thicknesses and ore grades 

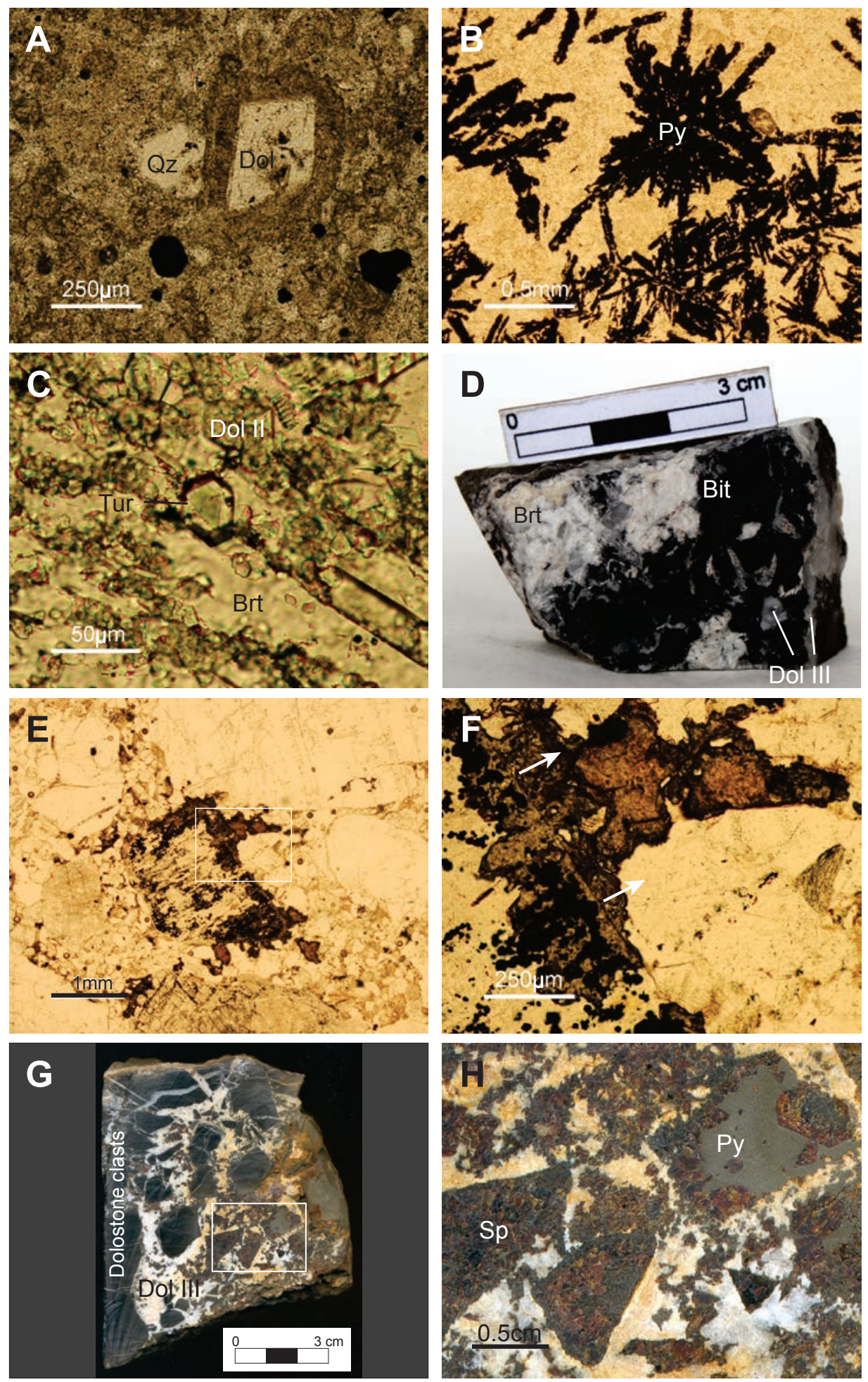

Fig. 2. Photomicrographs in plane-polarized transmitted light. (A) Dolomite crystal (Dol) from the carbonate transition zone with clear core and brown rim, which is similar to the dolomite crystals in the matrix. See also an idiomorphic quartz section (Qz) (sample ALT1-037.75; Altube). (B) Pyrite (Py) replacing tabular crystals (sulfate, marcasite [?]) in the carbonate transition zone (sample ALT1-031.05; Altube). (C) Tourmaline basal section (Tur) with green core and uncolored rim, enclosed in barite (Brt). Notice dolomite (Dol II) replacing barite (sample DM-02-02; Iturlum). (D) Hand specimen of ore-stage dolomite (Dol III) and barite (Brt) associated with bitumen (Bit) (sample DM-03-02; Jugo). (E) Sphalerite and pyrite partially replacing a quartzite clast (sample ALT8-231.60; Altube). (F) Detail of the previous image. Arrows point out the former clast limits. (G) Hand specimen of mineralized breccia in the carbonate transition zone with saddle white dolomite (Dol III) and sulfides partially replacing dolomitic clasts (sample DM-05-05; Aperregui). (H) Detail of the previous image. Notice the replacive nature of the mineralization with clasts partially or completely replaced by sphalerite $(\mathrm{Sp})$ and pyrite (Py). 


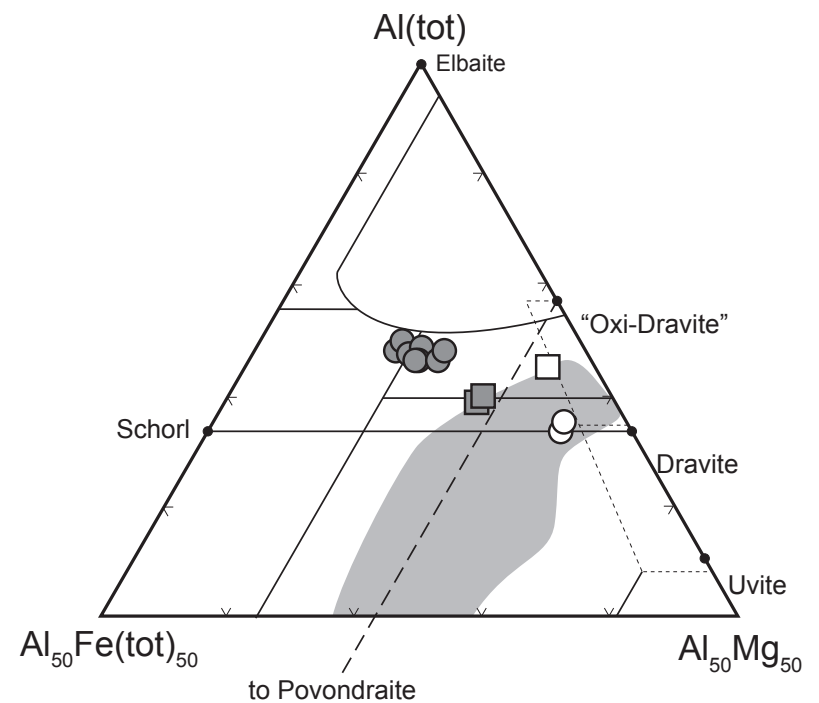

Fig. 3. Compositional variation of tourmalines from the carbonate transition zone in the Henry and Guidotti (1985) Al-Fe(tot)-Mg plot. The shaded field represents evaporite and metaevaporite rocks (Henry et al., 2008). Squares represent sample ALT2-225.90. Circles represent sample ALT6-230.50. Dark gray and white symbols show tourmaline cores and rims, respectively. Cores plot outside the shaded field and are considered inherited grains. Rims fall within the shaded field, indicating an authigenic origin.

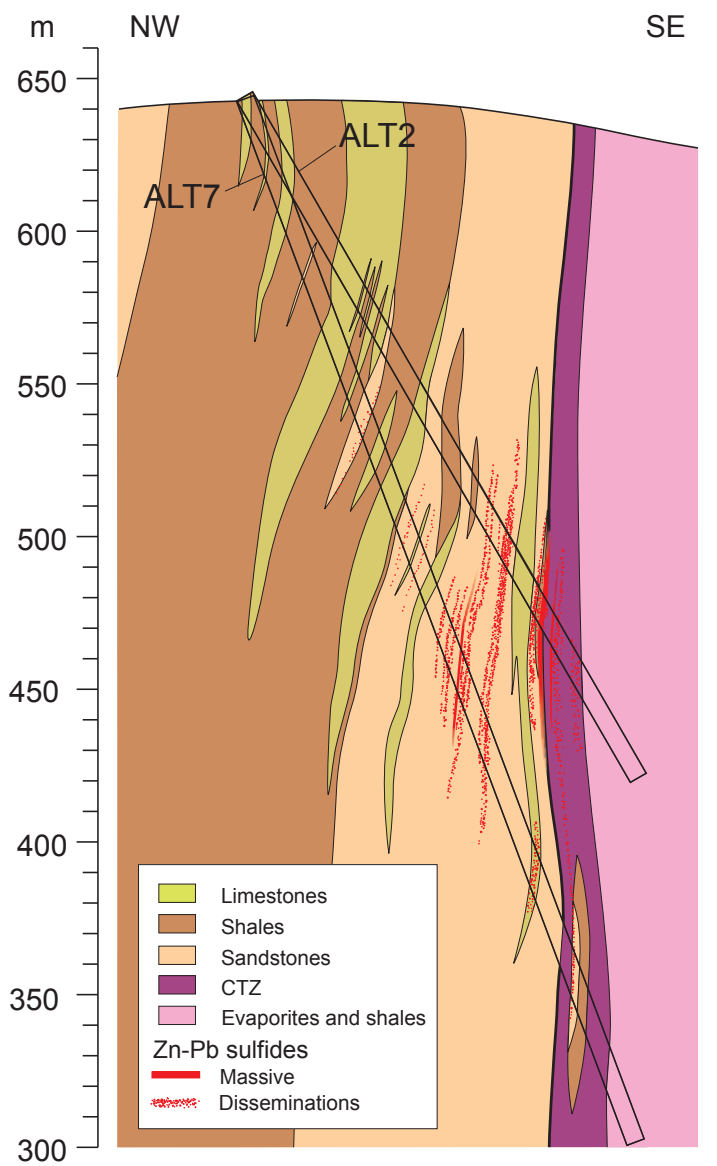

Fig. 4. Geologic cross section at the Altube prospect. ALT2 and ALT7 drill cores are shown. Note the main mineralized levels (red) located near the diapiric contact and enclosed within sandstones of the Valmaseda Formation (light brown) and the carbonate transition zone (CTZ; purple). increase toward the diapiric contact, where the carbonate transition zone sheath (up to $20 \mathrm{~m}$ thick) is cut. Mineralization is apparently concentrated in a 50-m-thick band, at $150-\mathrm{m}$ depth, comprising both the carbonate transition zone and the Valmaseda Formation (Fig. 4). Ore and gangue minerals are composed of sphalerite, galena, pyrite, calcite, dolomite, quartz, and bitumen.

Mineralization hosted in Upper Cenomanian to Lower Turonian dolomitized carbonates consists of $\mathrm{Zn}-\mathrm{Pb}$-Ba replacements and veins, up to $70 \mathrm{~cm}$ thick, running perpendicularly to the diapiric contacts (Compañia General de Sondeos, unpub. report, 1996). Mineralogy consists of sphalerite, minor galena, pyrite, dolomite, quartz, barite, albite, and bitumen.

Mineralization within the carbonate transition zone at Jugo, Aperregui, and Iturlum consists of veins and replacements (Fig. 2G, H). Ore minerals are the same as in Altube. Barite is abundant at Iturlum and Jugo (Fig. 2D), and albite is present at Aperregui, Iturlum, and Jugo.

A particular occurrence is found at Paúl, located at the southern border of the Orduña diapir (see Fig. 1). It consists of two black shale horizons ( 45 and $75 \mathrm{~cm}$ thick, respectively) with fine-grained disseminated to semimassive pyrite-rich sulfides (up to $3 \% \mathrm{Zn}$ ), interbedded within marls and limestones. They represent the oceanic anoxic event (OAE) that occurred at the Cenomanian-Turonian boundary (Jenkyns, 1980; Wilson and Norris, 2001). Drilling showed that ore horizons are up to $150 \mathrm{~m}$ long with a lesser lateral extent. Mineralization consists of pyrite, marcasite, sphalerite with minor galena, dolomite, and calcite. Small veins with similar paragenesis that underlie these disseminations have also been recognized.

\section{Mineralogy and Paragenetic Sequence}

After optical microscopy, cathodoluminescence, and microprobe analyses, a similar mineralogy and paragenetic sequence was deduced for all studied deposits (Fig. 5). Barite and replacive dolomite predate sulfides (sphalerite, galena, and pyrite/marcasite), which are contemporaneous to saddle dolomite. A brief description of ore and gangue minerals is given below.

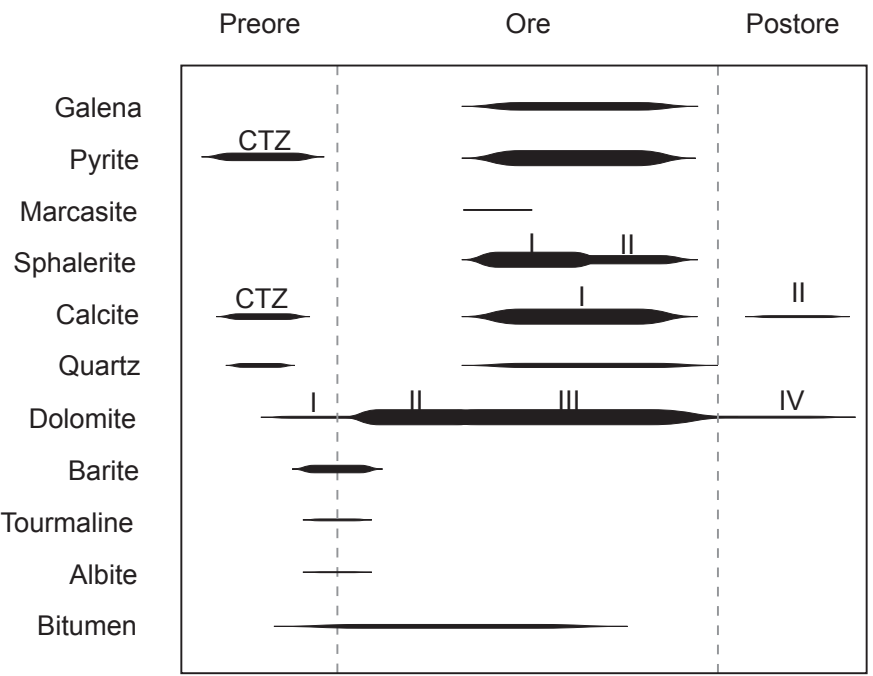

Fig. 5. Paragenetic sequence for the studied deposits. CTZ = carbonate transition zone. Timing is Cretaceous. 
Sphalerite is present as allotriomorphic to idiomorphic crystals ranging in size from $<1 \mathrm{~mm}$ up to $5 \mathrm{~cm}$. Fe and Cd content is up to 2 and 0.5 wt \%, respectively, and Ge, Ga, In, and $\mathrm{Hg}$ are below the detection limit (Perona, 2016). From cathodoluminescence, two sphalerite types (I and II), have been distinguished. Sphalerite I is characterized by nonluminescent crystals, whereas sphalerite II shows oscillatory dark, brightyellow cathodoluminescent micron-scale banding. Sphalerite II fills small veinlets or appears as overgrowths around sphalerite I (Fig. 6A, B). Both types are chemically similar, although luminescent bands in sphalerite II have slightly lower $\mathrm{Cd}$ and $\mathrm{Fe}$ contents. Galena occurs as disseminated crystals or fills cracks in sphalerite (I and II). Pyrite is ubiquitous in all deposits. It is found as idiomorphic (pyritohedra) to subidiomorphic disseminated crystals (up to $1 \mathrm{~mm}$ ) often associated with organic matter and as a $<5-\mu \mathrm{m}$ discontinuous rim around some sphalerite crystals (Fig. 6C). Pyrite-rich zones in the Valmaseda Formation are not always related to $\mathrm{Zn}-\mathrm{Pb}$ sulfides.

According to crystal shape and size, extinction type, cathodoluminescence, and macroscopic color, four dolomite types have been distinguished. Not all types appear in the same locality, and a gradual transition between types I, II, and III is observed. Dolomite I is made up of 10 - to $25-\mu \mathrm{m}$, nonluminescent idiomorphic replacive crystals. Dolomite II corresponds to nonluminescent idiomorphic crystals of 40 to $50 \mu \mathrm{m}$. Dolomite III is of the saddle type, related to ore sulfides, with crystal sizes up to $1 \mathrm{~cm}$, showing red luminescence, occasionally with a nonluminescent core. Finally, dolomite IV consists of 500 - to $1,000-\mu \mathrm{m}$ red luminescent saddle-type crystals, found in veinlets that crosscut all previous dolomite types.

Two calcites have been distinguished: ore-related calcite I, characterized by weak to bright homogeneous orange cathodoluminescence with crystal sizes up to $10 \mathrm{~cm}$, and calcite II, a late-phase crosscutting ore and gangue minerals. The latter shows banded bright-orange cathodoluminescence zoning and crystal sizes from $50 \mu \mathrm{m}$ to $5 \mathrm{~mm}$.

Barite occurs as veins and breccia fillings at Iturlum, Jugo, and Beluntza, always related to an early mineralization stage. At Iturlum it shows a bimodal crystal size distribution with large (1-2 cm) crystals that coexist with millimeter-size crystals. Barite shows weak blue cathodoluminescence and is partially replaced by dolomite II.

Bitumen appears all along the paragenetic sequence and formed after liquid hydrocarbons, as evidenced by fluidal textures (Fig. 6D). Solidification took place before or during the precipitation of the $\mathrm{Zn}-\mathrm{Pb}$ sulfides, as suggested by fractures and vesicles filled with sulfides, sulfates, and carbonates. Organic matter and sulfides are spatially related (Fig. 6E, F), and degassing textures in bitumen are observed (Fig. 6E, G) (see next section).

\section{Organic Matter Characterization}

Organic matter is mainly present as bitumen. In all deposits except Altube, bitumen reflectance $\left(\mathrm{BR}_{0}\right)$ is isotropic, with mean values ranging from 1.24 (Artomaña) to $3.5 \%$ (Aperregui) (Table 1). At Altube, anisotropy is related to mosaic and fluidal textures. In this deposit, nine of the 16 measured samples were isotropic, with $\mathrm{BR}_{0}$ values from 2.76 to $3.22 \%$, equivalent to vitrinite reflectances ( $\mathrm{R}_{0}$ eq.) between 2.81 and $3.19 \%$, according to the equation of Schoenherr et al.
(2007). Using the equation of Barker and Pawlewicz (1994), which relates $\mathrm{R}_{0}$ and temperature for hydrothermal maturation $\left(\mathrm{T}\left[{ }^{\circ} \mathrm{C}\right]=\left[\mathrm{LnR}_{0}+1.19\right] / 0.00782\right)$, a range between $284^{\circ}$ and $300^{\circ} \mathrm{C}$ was obtained. The lowest reflectivity measured is found on samples from the Villasana de Mena diapir $\left(\mathrm{BR}_{0}\right.$ mean value $0.75 \%$ ). It is important to note that the dispersion of $\mathrm{RB}_{0}$ values within the same occurrence is high, and therefore the temperature/ $\mathrm{RB}_{0}$ correlation is not straightforward.

Total organic carbon, $\mathrm{T}_{\max }$, and hydrogen index from RockEval are shown in Table 1. In whole-rock samples from Murguía (Altube) and the Villasana de Mena diapirs, total organic carbon varies from 0.1 to $7.0 \%$ and $\mathrm{T}_{\max }$ from $430^{\circ}$ to $630^{\circ} \mathrm{C}$. The highest $\mathrm{T}_{\max }$ values were obtained at Altube, indicating that organic matter is overmatured, in agreement with the anisotropic character of bitumen in some samples (see Table 1 ). As the bitumen $T_{\max }$ is within the whole-rock $T_{\max }$ range, it has also been used as a thermal indicator. The lowest $\mathrm{T}_{\text {max }}$ and highest hydrogen index were found at Villasana de Mena plotting within the catagenesis field, whereas all the other samples, including bitumen from Jugo, Aperregui, and Artomaña, plot within the metagenesis field (Fig. 7).

The less matured samples inferred from Rock-Eval match with those of the lowest $\mathrm{BR}_{0}$, showing that both thermal indicators are consistent. Large variations in $\mathrm{BR}_{0}$ and Rock-Eval in samples from the Murguía diapir have been measured: bitumen from Altube and Aperregui shows high $\mathrm{BR}_{0}$ and $\mathrm{T}_{\max }$, whereas at Jugo these indicators are clearly lower (see Table 1).

\section{Stable Isotope Data}

Carbon and oxygen isotope analyses were performed on 256 carbonate samples, including Cretaceous host rocks $(n=38)$, carbonates related to ores $(n=151)$, and carbonates from the transition zone $(n=67)$. Results are shown in Table 2 and Figure 8.

The ${ }^{13} \mathrm{C}$ and $\delta^{18} \mathrm{O}$ values of marine limestones of Cenomanian and Turonian age around the diapirs range from 0.5 to $2.8 \%$ and from 23.0 to $27.3 \%$, respectively $(n=11)$. Interbedded carbonate levels within the Valmaseda Formation (Late Albian to Early Cenomanian) show $\delta^{13} \mathrm{C}$ and $\delta^{18} \mathrm{O}$ values of -1.7 to $1.6 \%$ and 18.8 to $26.7 \%$ o $(n=6)$, respectively, lower than local marine limestones.

At Altube, ore-stage calcite (cal I) from mineralization associated with the Valmaseda Formation has $\delta^{13} \mathrm{C}$ values from -4.9 to $2.4 \%$ and $\delta^{18} \mathrm{O}$ values from 17.3 to $20.1 \%$, respectively $(n=20)$. Late calcite (cal II) has $\delta^{13} \mathrm{C}$ values from -5.4 to $1.8 \%$ and $\delta^{18} \mathrm{O}$ values from 16.6 to $22.5 \%(n=9)$. Orestage dolomite has a $\delta^{13} \mathrm{C}$ value from -3.2 to $3.5 \%$ and a $\delta^{18} \mathrm{O}$ value from 17.6 to $20.0 \%(n=10)$.

At Jugo, $\delta^{13} \mathrm{C}$ and $\delta^{18} \mathrm{O}$ values of dolomite vary from -12.3 to $2.2 \%$ and from 21.3 to $24.5 \%(n=16)$, respectively. Preore dolomite (dol I and II) values vary from -7.5 to $2.2 \%$ and from 21.3 to $24.5 \%$ o $(n=8)$, respectively; ore-stage (dol III) values range from -10 to $-5.4 \%$ and 22.4 to $24.5 \%$ ( $(n=6)$, and postore (dol IV) values from -12.3 to $-12.1 \%$ and from 23.5 to $23.6 \%(n=2)$. The $\delta^{13} \mathrm{C}$ and $\delta^{18} \mathrm{O}$ values of ore-stage calcite (cal I) range from -3.6 to $-0.9 \%$ and from 21.6 to $23.2 \%$ ( $n=3)$.

At Aperregui, $\delta^{13} \mathrm{C}$ and $\delta^{18} \mathrm{O}$ values vary from -5.1 to $-4.4 \%$ and from 21.1 to $22.8 \%(n=4)$ in preore dolomite (dol II), from -9.2 to $-7.7 \%$ and 22.1 to $22.8 \%(n=4)$ in ore-stage 

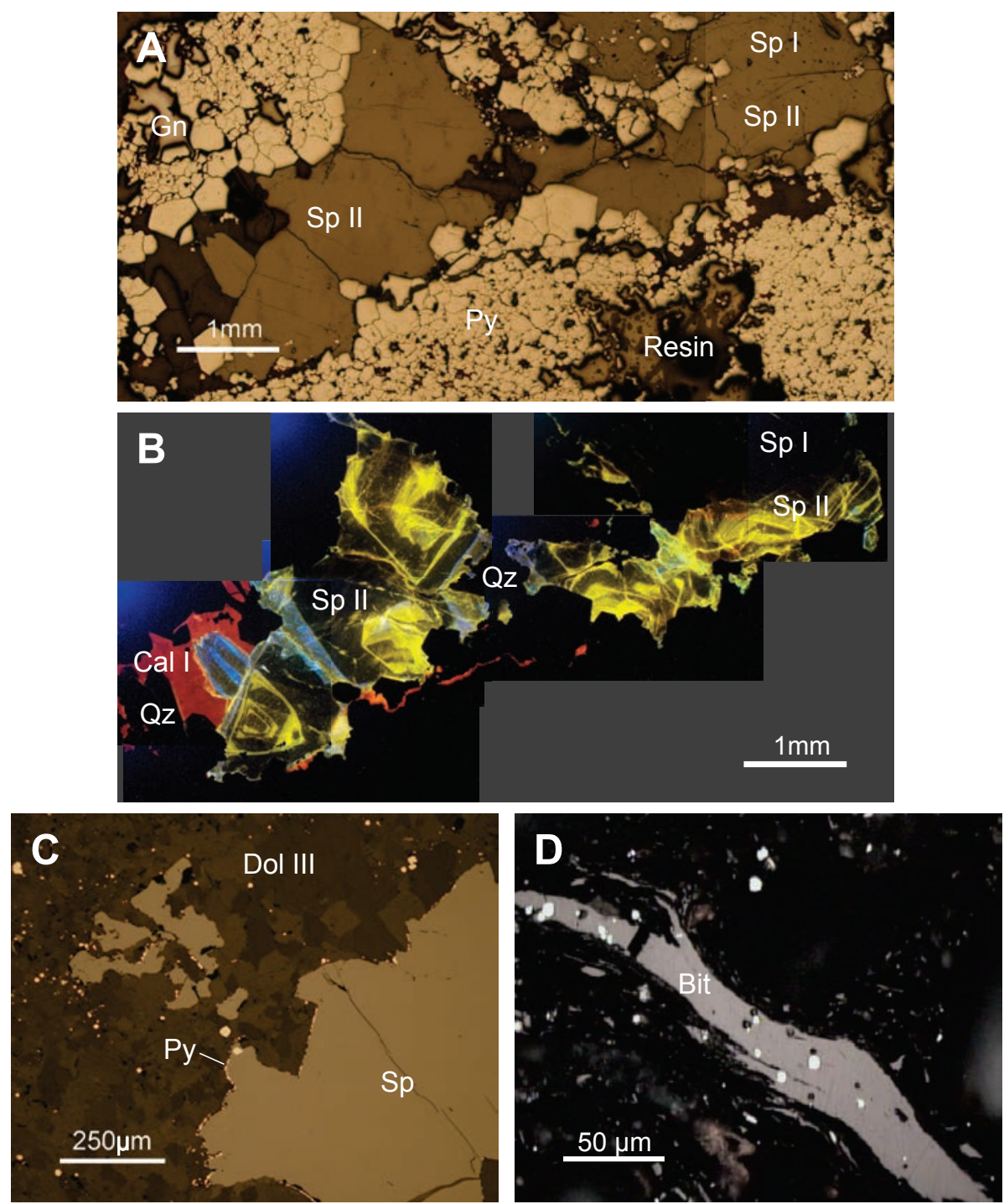

Fig. 6. Photomicrographs in plane-polarized reflected light. (A) Massive pyrite (Py), galena (Gn), and sphalerite (Sp I) crosscut by sphalerite (Sp II) (sample ALT2-198.30; Altube). (B) Same image under cathodoluminescence with quartz (Qz) and calcite (Cal I) within the veinlet. Notice the zoned yellow luminescence of sphalerite II, and the nonluminescence of sphalerite I. (C) Thin pyrite (Py) rim around sphalerite-dolomite (Dol III) interphase (sample DM-05-01; Aperregui), resulting from an incomplete replacement of pyrite by sphalerite (Sp). (D) Anisotropic bitumen (Bit) showing fluidal texture. The white mineral is pyrite (sample FV-22; Valmaseda Formation, Altube). (E) Photomicrograph in plane-polarized transmitted light of a sphalerite crystal growing from bitumen showing degassing textures (A: vesicles) and oily impregnations (dotted line) (sample ALT3-040.90; Altube). (F) Degassing vesicles in bitumen filled with framboidal pyrite (Py fr) and sphalerite (sample ALT7-233.70; Altube). These textures indicate a (G) Fusinite maceral (A) partially replaced by sphalerite and pyrite (sample DM-01-3; Altube).

dolomite (dol III), and from -13.7 to $-12.3 \%$ and from 22.5 to $23.1 \%(n=4)$ in postore dolomite (dol IV), respectively.

At Montaleón preore dolomite $\delta^{13} \mathrm{C}$ and $\delta^{18} \mathrm{O}$ values range from -2.2 to $0.7 \%$ and from 23.0 to $24.7 \%$ ( $n=7)$, respectively. Ore-stage dolomite ( $\mathrm{dol}$ III) values range from -4.9 to $1.0 \%$ and from 22.2 to $25.9 \%(n=27)$, and a single data for postore dolomite (dol IV) gave values of $\delta^{13} \mathrm{C}=-1.6 \%$ and $\delta^{18} \mathrm{O}=26.7 \%$. The $\delta^{13} \mathrm{C}$ and $\delta^{18} \mathrm{O}$ values of ore-stage calcite (cal I) range from -3.6 to $-0.9 \%$ and from 21.6 to $23.2 \%$ ( $n=$ $3)$, respectively.

At Paul, ore-stage dolomite (dol III) $\delta^{13} \mathrm{C}$ and $\delta^{18} \mathrm{O}$ values range from 2.3 to $3.2 \%$ and from 26.4 to $27.4 \%$ o $(n=12)$, and ore-stage calcite (cal I) $\delta^{13} \mathrm{C}$ and $\delta^{18} \mathrm{O}$ values range from 0.7 to $2.1 \%$ and from 23.7 to $25.1 \% 0(n=14)$, respectively. A late calcite sample (cal II) has $\delta^{13} \mathrm{C}$ and $\delta^{18} \mathrm{O}$ values of 1.7 and $21.7 \%$.

Carbon isotope composition of greenish brecciated and zebra dolostones from the carbonate transition zone is significantly ${ }^{13} \mathrm{C}$ depleted, with $\delta^{13} \mathrm{C}$ values from -20.5 to $0.9 \%$ ( $n=$ 37). However, $\delta^{18} \mathrm{O}$ values are within the range obtained for other carbonate samples: 18.8 to $26.6 \%$.

A total of 136 sulfides and 19 sulfates were analyzed for their sulfur isotope composition and results are shown in Figure 9 and Table 3 . The sulfur isotope composition ranges from 

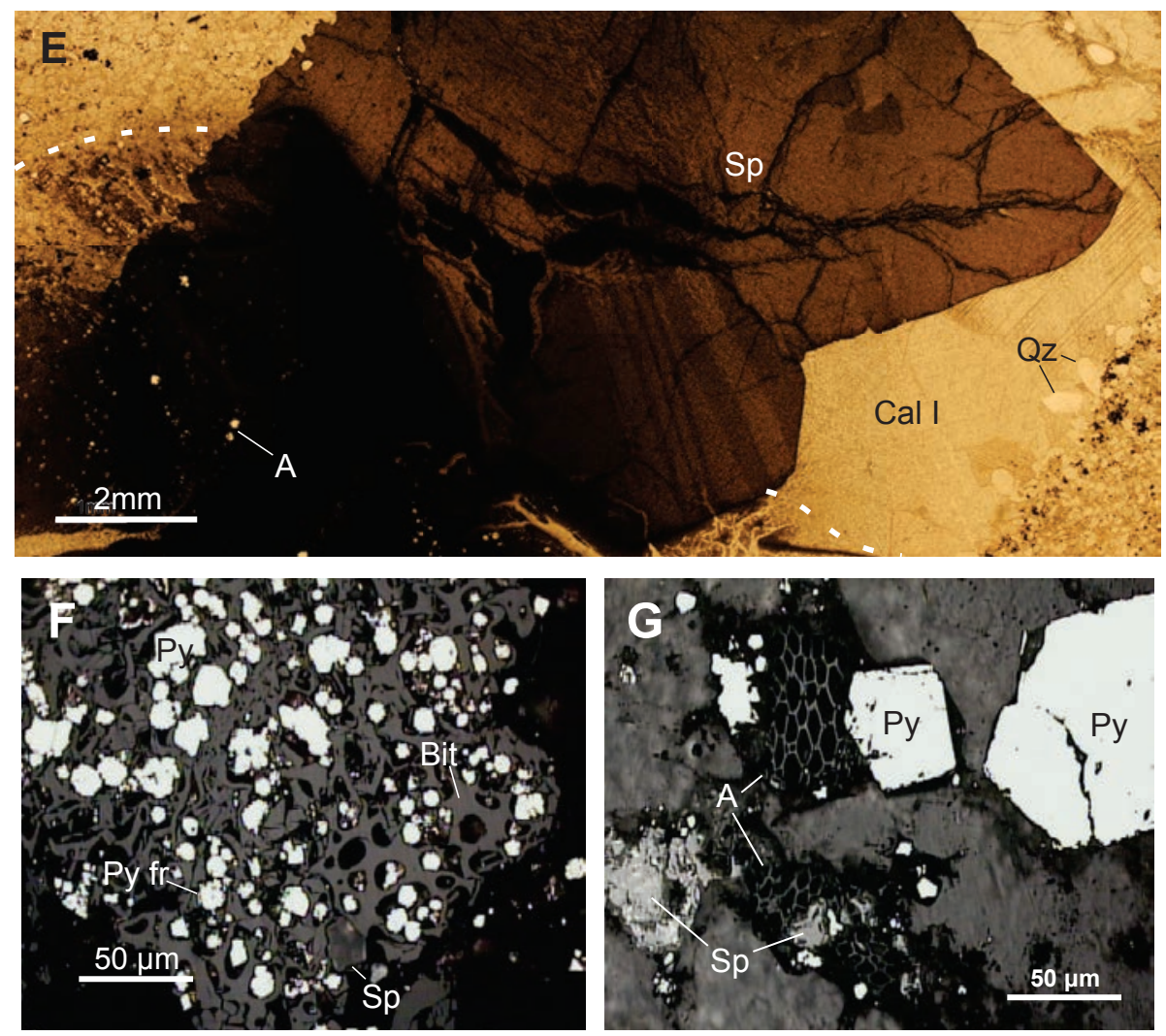

Fig. 6. (Cont.)

4.1 to $12 \%$ ( $n=34$ ) for galena and from 4.6 to $15.1 \%$ for sphalerite $(n=47)$. Pyrite shows a broad range, from -41.5 to $48.1 \%$ ( $n=54)$, although most samples $(85 \%)$ lie between 3.4 and $28.8 \%$. Barite is isotopically enriched in ${ }^{34} \mathrm{~S}$ with respect to sulfides, having $\delta^{34} \mathrm{~S}$ values from 16.2 to $24.3 \%$ ( $\left.n=14\right)$. Evaporitic gypsum of the Keuper facies (Upper Triassic) sampled in a drill core from Altube has a $\delta^{34} \mathrm{~S}$ from 15.3 to $17.4 \%$ $(n=4)$. Two sphalerites from Villasana de Mena diapir gave lower $\delta^{34} \mathrm{~S}$ values $(-1.4$ and $0.2 \%)$, whereas barite $\left(\delta^{34} \mathrm{~S}=\right.$

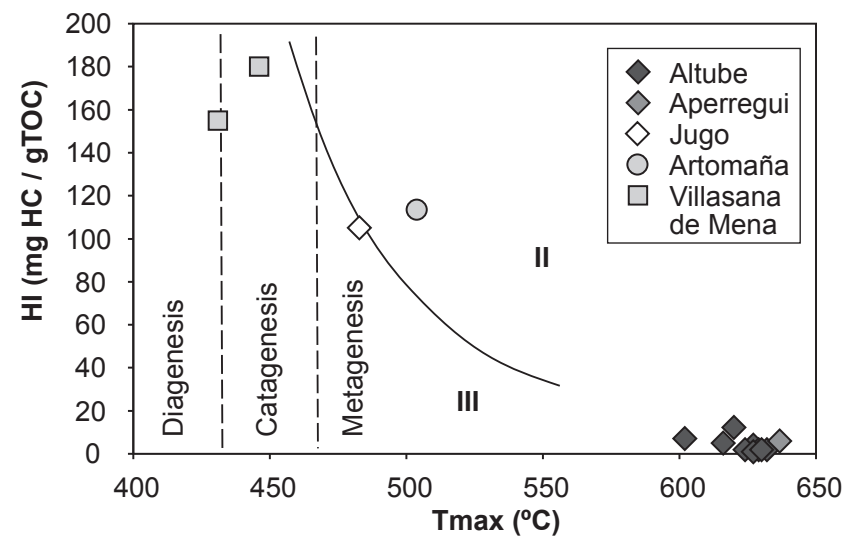

Fig. 7. Plot of hydrogen index (HI) vs. pyrolysis $\mathrm{T}_{\max }$, showing kerogen-type and thermal maturity stages of organic matter related to mineralization in the Murguía, Orduña, and Villasana de Mena diapirs. II and III refer to kerogen type. TOC = total organic carbon.
$17.6 \%$ ) falls within the range of the other studied deposits. Geothermometrical calculations, using the Czamanske and Rye (1974) equation, were performed on 23 sphalerite-galena pairs: 10 from Altube, six from Montaleón, three from Jugo, two from Beluntza, and two from Paúl (Fig. 10). Equilibrium temperatures show a wide range $\left(80^{\circ}-300^{\circ} \mathrm{C}\right)$, although 10 pairs fall between $150^{\circ}$ and $200^{\circ} \mathrm{C}$ (mean $178 \pm 7^{\circ} \mathrm{C}$ ).

\section{Radiogenic Isotopes}

Ten carbonates - from Altube (two ore-stage calcites, two carbonate transition zone calcites), Jugo (two ore-stage calcites), Montaleón (two ore-stage calcites), and Paúl (two ore-stage dolomites)—were analyzed for their ${ }^{87} \mathrm{Sr} /{ }^{86} \mathrm{Sr}$ ratios. Results are shown in Table $2 .{ }^{87} \mathrm{Sr} /{ }^{86} \mathrm{Sr}$ ratios of ore-stage carbonates (calcite and dolomite) range from 0.71052 to 0.71202 in sandstone-hosted mineralization and from 0.70801 to 0.71116 in carbonate-hosted mineralization. Generally, ${ }^{87} \mathrm{Sr} /{ }^{86} \mathrm{Sr}$ ratios of carbonates are higher when the associated mineralization is enclosed within the Valmaseda Formation, which is predominantly siliciclastic.

Nine galena samples from Altube, Jugo, Montaleón, La Antigua, Beluntza, and Paúl were analyzed for their Pb isotope composition. Results are shown in Table 4 and Figure $11 \mathrm{~B}$. ${ }^{206} \mathrm{~Pb} /{ }^{204} \mathrm{~Pb}$ ratios of galenas range from 18.643 to 18.696; ${ }^{207} \mathrm{~Pb} /{ }^{204} \mathrm{~Pb}$ ratios range between 15.650 and 15.676 , and ${ }^{208} \mathrm{~Pb} /{ }^{204} \mathrm{~Pb}$ ratios range between 38.720 and 38.780 . In the uranogenic diagram, data plot on a Stacey and Kramers growth curve with a $\mu$ between 9.6 and 9.8 , and in the thorogenic diagram, with $\kappa$ values from 3.80 to 3.98 . 
Table 1. Bitumen Reflectance $\left(\mathrm{BR}_{0} \%\right)$ and Rock-Eval Data ( $\mathrm{T}_{\max }$, TOC, HI, and OI)

\begin{tabular}{|c|c|c|c|c|c|c|c|c|c|c|}
\hline \multirow[t]{2}{*}{ Sample } & \multirow[t]{2}{*}{ Lithology } & \multicolumn{5}{|c|}{$\mathrm{BR}_{0} \%$} & \multirow{2}{*}{$\begin{array}{l}\mathrm{T}_{\max } \\
\left({ }^{\circ} \mathrm{C}\right) \\
\end{array}$} & \multirow{2}{*}{$\begin{array}{c}\text { TOC } \\
(\%) \\
\end{array}$} & \multirow{2}{*}{$\frac{\text { HI }}{\left(\begin{array}{c}\mathrm{mg} \mathrm{HC} / \\
\text { g TOC })\end{array}\right.}$} & \multirow{2}{*}{ 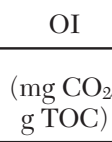 } \\
\hline & & Range & Mode & $\begin{array}{l}\text { Standard } \\
\text { deviation }\end{array}$ & $n$ & Character & & & & \\
\hline \multirow{2}{*}{\multicolumn{11}{|c|}{$\begin{array}{l}\text { Murgia diapir } \\
\text { Altube }\end{array}$}} \\
\hline & & & & & & & & & & \\
\hline ALT-NM & Sandstone & & & & & & - & 0.2 & - & - \\
\hline DM-01-03 & Sandstone & $2.17-3.11$ & 2.80 & 0.12 & 274 & Isotropic & 602 & 7.0 & 7 & 15 \\
\hline ALT2-180.10 & Sandstone & $2.18-3.32$ & 2.92 & 0.25 & 42 & Isotropic & & & & \\
\hline ALT3-328.00 & Dolostone & $2.21-3.34$ & 2.90 & 0.22 & 58 & Isotropic & & & & \\
\hline ALT6-195.50 & Limestone & $2.03-3.19$ & 2.62 & 0.31 & 56 & Isotropic & & & & \\
\hline ALT6-201.40 & Calcite vein & $2.51-3.12$ & 2.88 & 0.10 & 202 & Isotropic & & & & \\
\hline ALT6-206.70 & CTZ & $2.71-3.47$ & 3.22 & 0.15 & 107 & Isotropic & & & & \\
\hline ALT7-023.85 & Shale & $1.87-3.03$ & 2.46 & 0.24 & 266 & Anisotropic & & & & \\
\hline ALT7-045.85 & Shale & $1.53-3.28$ & 2.56 & 0.22 & 294 & Anisotropic & & & & \\
\hline ALT-7 159,95 & Shale & & & & & & - & 1.4 & - & - \\
\hline ALT-7 189,20 & Shale & & & & & & 627 & 3.4 & 4 & 13 \\
\hline ALT-7 193,75 & Sandstone & & & & & & - & 0.2 & - & - \\
\hline ALT7-194.30 & Sandstone & $2.20-4.00$ & 2.76 & 0.28 & 242 & Isotropic & & & & \\
\hline ALT-7 197,50 & Sandstone & & & & & & - & 0.0 & - & - \\
\hline ALT-7 207,00 & Shale & & & & & & - & 4.3 & - & - \\
\hline ALT-7 210,00 & Sandstone & & & & & & - & 0.0 & - & - \\
\hline ALT-7 211,80 & Sandstone & & & & & & 616 & 5.0 & 5 & 7 \\
\hline ALT-7 213,60 & Shale & & & & & & 624 & 4.2 & 2 & 7 \\
\hline ALT-7 218,90 & Shale & & & & & & 629 & 1.3 & 2 & 18 \\
\hline ALT-7 221,75 & Shale & & & & & & 632 & 2.3 & 2 & 14 \\
\hline ALT7-211.80 & Sandstone & $2.15-3.61$ & 2.80 & 0.27 & 132 & Anisotropic & & & & \\
\hline ALT7-228.30 & Sandstone & $2.03-3.44$ & 2.63 & 0.15 & 291 & Anisotropic & 620 & 82.3 & 12 & 0 \\
\hline ALT7-231.50 & Sandstone & $1.76-3.48$ & 2.65 & 0.30 & 333 & Anisotropic & 627 & 1.5 & 1 & 12 \\
\hline ALT7-233.70 & Sandstone & $2.13-3.15$ & 2.86 & 0.22 & 212 & Isotropic & - & 0.8 & - & - \\
\hline ALT-7 234,00 & Sandstone & & & & & & - & 0.2 & - & - \\
\hline ALT-7 236,15 & Shale & & & & & & 630 & 1.1 & 2 & 26 \\
\hline ALT-7 273,40 & Shale & & & & & & - & 0.6 & - & - \\
\hline ALT-7 276,20 & Dolostone & & & & & & - & 0.6 & - & - \\
\hline ALT7-283.50 & Sandstone & $2.28-3.25$ & 2.71 & 0.15 & 302 & Anisotropic & & & & \\
\hline ALT7-297.50 & Sandstone & $2.53-3.61$ & 3.11 & 0.15 & 224 & Anisotropic & - & 1.0 & - & - \\
\hline ALT-7 313,25 & Sandstone & & & & & & - & 0.5 & - & - \\
\hline ALT-7 318,90 & Shale & & & & & & - & 1.1 & - & - \\
\hline ALT9-160.60 & Calcite vein & $2.49-3.33$ & 2.94 & 0.16 & 34 & Isotropic & & & & \\
\hline FV-6 & Black shale & & & & & & 613 & 0.9 & 8 & 72 \\
\hline \multicolumn{11}{|l|}{ Jugo } \\
\hline JU-1 & Sandstone & $1.01-1.46$ & 1.33 & 0.13 & 39 & Isotropic & & & & \\
\hline DM-03-02 & Dolomitic breccia & $1.38-1.77$ & 1.59 & 0.08 & 90 & Isotropic & 483 & 63.3 & 105 & 3 \\
\hline DM-05-04 & Dolostone & & & & & & - & 0.1 & - & - \\
\hline \multicolumn{11}{|l|}{ Aperregui } \\
\hline DM-05-04 & Dolomitic breccia & $3.21-3.71$ & 3.48 & 0.08 & 299 & Isotropic & 637 & 84.0 & 6 & 9 \\
\hline DM-05-04 & Breccia clast & & & & & & - & 0.3 & - & - \\
\hline \multicolumn{11}{|l|}{ Orduña diapir } \\
\hline \multicolumn{11}{|l|}{ Artomaña } \\
\hline DO-01-01 & Dolomitic breccia & $1.07-1.38$ & 1.23 & 0.05 & 197 & Isotropic & 504 & 44.0 & 114 & 3 \\
\hline DO-01-01 & Breccia clast & & & & & & - & 0.1 & - & - \\
\hline \multicolumn{11}{|l|}{ La Antigua } \\
\hline DO-02-04 & Dolostone & & & & & & - & 0.3 & - & - \\
\hline \multicolumn{11}{|l|}{ Montaleón } \\
\hline DO-03-02 & Dolostone & $2.53-4.36$ & - & 0.47 & 14 & Isotropic & - & 0.2 & - & - \\
\hline DO-03-06 & Dolostone & $3.15-4.53$ & 3.76 & 0.24 & 87 & Isotropic & - & 0.2 & - & - \\
\hline \multicolumn{11}{|l|}{ Paúl } \\
\hline DO-04-NI & Black shale & $0.42-5.39$ & 1.99 & 0.77 & 506 & Isotropic & - & 0.3 & - & \\
\hline DO-04-NS & Black shale & $0.61-4.67$ & 1.85 & 0.88 & 193 & Isotropic & & & & \\
\hline
\end{tabular}


Table 1. (Cont.)

\begin{tabular}{|c|c|c|c|c|c|c|c|c|c|c|}
\hline \multirow[t]{2}{*}{ Sample } & \multirow[t]{2}{*}{ Lithology } & \multicolumn{5}{|c|}{$\mathrm{BR}_{0} \%$} & \multirow{2}{*}{$\begin{array}{l}\mathrm{T}_{\max } \\
\left({ }^{\circ} \mathrm{C}\right) \\
\end{array}$} & \multirow{2}{*}{$\begin{array}{l}\text { TOC } \\
(\%) \\
\end{array}$} & \multirow{2}{*}{ 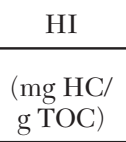 } & \multirow{2}{*}{$\frac{\mathrm{OI}}{\left(\begin{array}{c}\mathrm{mg} \mathrm{CO} \\
\mathrm{g} \text { TOC })\end{array}\right.}$} \\
\hline & & Range & Mode & $\begin{array}{l}\text { Standard } \\
\text { deviation }\end{array}$ & $n$ & Character & & & & \\
\hline \multicolumn{11}{|c|}{ Villasana de Mena diapir } \\
\hline VM-02-03 & Sandstone & $0.51-1.45$ & 0.99 & 0.31 & 285 & Isotropic & 446 & 2.51 & 180 & 16 \\
\hline VM-02-10B & Sandstone & $0.14-2.02$ & 0.45 & 0.49 & 203 & Isotropic & 431 & 0.96 & 155 & 31 \\
\hline \multicolumn{11}{|c|}{ Valmaseda Formation } \\
\hline FV-17 & Sandstone & & & & & & - & 0.0 & - & - \\
\hline FV-18 & Sandstone & & & & & & - & 0.0 & - & - \\
\hline FV-19 & Sandstone & & & & & & - & 0.1 & - & - \\
\hline FV-21 & Sandstone & & & & & & 630 & 1.2 & 2 & 16 \\
\hline FV-22 & Sandstone & $3.07-4.65$ & 3.55 & 0.26 & 140 & Anisotropic & & & & \\
\hline
\end{tabular}

Abbreviations: $\mathrm{CTZ}=$ carbonate transition zone, $\mathrm{HI}=$ hydrogen index, $\mathrm{OI}=$ oxgen index, $\mathrm{T}_{\max }=$ temperature of the maximum rate of hydrocarbon generation, TOC $=$ total organic carbon

Table 2. $\delta^{13} \mathrm{C}-\delta^{18} \mathrm{O}$ of Carbonates

\begin{tabular}{|c|c|c|c|c|c|}
\hline Sample & Mineral & $\begin{array}{c}\delta^{13} \mathrm{C} \\
(\% o \mathrm{~V}-\mathrm{PDB})\end{array}$ & $\begin{array}{c}\delta^{18} \mathrm{O} \\
(\% o \mathrm{~V}-\mathrm{SMOW})\end{array}$ & ${ }^{87} \mathrm{Sr} / 86 \mathrm{Sr}$ & Observations \\
\hline \multicolumn{6}{|l|}{ Murguía diapir } \\
\hline \multicolumn{6}{|l|}{ Altube } \\
\hline \multicolumn{6}{|l|}{ Host rock } \\
\hline ALT1-110.70 & Calcite & 0.5 & 20.4 & & Carbonate beds in Valmaseda Fm. \\
\hline ALT3 036.70 & Calcite & 0.1 & 20.0 & & Carbonate beds in Valmaseda Fm. \\
\hline ALT4-133.85 & Calcite & -1.7 & 18.8 & & Carbonate beds in Valmaseda Fm., high detrital and bioclast content \\
\hline ALT6-145.30 & Calcite & 1.5 & 20.0 & & Carbonate beds in Valmaseda Fm. \\
\hline ALT3-328.00 & Dolomite & -5.2 & 20.9 & & Dolomitized carbonate bed with high detrital content \\
\hline ALT7-276.20 & Dolomite & -2.1 & 20.9 & & Dolomitized carbonate bed with sphalerite and galena disseminations \\
\hline ALT1-134.50 & Calcite & -1.0 & 22.8 & & Replacive diagenetic cement in Valmaseda Fm. \\
\hline ALT3-023.00 & Calcite & -2.0 & 19.4 & & Replacive diagenetic cement in Valmaseda Fm. \\
\hline ALT3-040.90 & Calcite & 0.1 & 21.6 & & Replacive diagenetic cement in Valmaseda Fm. \\
\hline ALT6-198.00 & Calcite & -0.4 & 20.8 & & Replacive diagenetic cement in Valmaseda Fm. \\
\hline ALT7-194.30 & Calcite & 0.5 & 19.3 & & Replacive diagenetic cement in Valmaseda Fm. \\
\hline ALT7-197.50 & Calcite & -1.8 & 20.4 & & Replacive diagenetic cement in Valmaseda Fm. \\
\hline ALT7-283.50 & Calcite & -13.2 & 17.4 & & Replacive diagenetic cement in Valmaseda Fm. \\
\hline ALT7-283.50 & Calcite & -13.6 & 17.4 & & Replacive diagenetic cement in Valmaseda Fm. \\
\hline ALT7-283.50 & Calcite & -14.5 & 17.1 & & Replacive diagenetic cement in Valmaseda Fm. \\
\hline \multicolumn{6}{|l|}{ CTZ } \\
\hline ALT9-137.90 & Calcite & -3.7 & 18.2 & & Green carbonated rock \\
\hline ALT1-023.60 & Dolomite & -7.0 & 22.1 & & Greenish dolostone with phyllosilicates \\
\hline ALT1-026.80 & Dolomite & -7.1 & 23.2 & & Greenish dolostone with phyllosilicates \\
\hline ALT1-026.80 & Dolomite & -6.8 & 25.0 & & Greenish dolostone with phyllosilicates \\
\hline ALT1-029.80 & Dolomite & -6.4 & 19.6 & & Greenish dolostone with phyllosilicates \\
\hline ALT1-031.80 & Dolomite & -6.2 & 22.7 & & Greenish dolostone with phyllosilicates \\
\hline ALT1-032.00 & Dolomite & -3.1 & 23.2 & & Greenish dolostone with phyllosilicates \\
\hline ALT1-035.80 & Dolomite & -5.7 & 25.0 & & Greenish dolostone with phyllosilicates \\
\hline ALT1-037.75 & Dolomite & -5.2 & 25.2 & & Greenish dolostone with phyllosilicates \\
\hline ALT1-037.75 & Dolomite & -5.3 & 24.3 & & Greenish dolostone with phyllosilicates \\
\hline ALT1-037.75 & Dolomite & -9.9 & 25.8 & & Greenish dolostone with phyllosilicates \\
\hline ALT1-041.10 & Dolomite & -11.2 & 25.2 & & Greenish dolostone with phyllosilicates \\
\hline ALT1-046.00 & Dolomite & -0.9 & 18.8 & & Greenish dolostone with phyllosilicates \\
\hline ALT2-225.90 & Dolomite & 0.9 & 19.8 & & Greenish dolostone with phyllosilicates \\
\hline ALT3-341.80 & Dolomite & -6.4 & 19.5 & & Greenish dolostone with phyllosilicates \\
\hline ALT6-206.70 & Dolomite & -4.7 & 21.9 & & Greenish dolostone with phyllosilicates \\
\hline ALT6-224.00 & Dolomite & -3.4 & 21.0 & & Greenish dolostone with phyllosilicates \\
\hline ALT6-230.50 & Dolomite & -1.1 & 20.3 & & Greenish dolostone with phyllosilicates \\
\hline ALT6-239.50 & Dolomite & -4.5 & 20.5 & & Greenish dolostone with phyllosilicates \\
\hline ALT7-307.50 & Dolomite & -9.9 & 23.9 & & Greenish dolostone with phyllosilicates \\
\hline ALT7-308.00 & Dolomite & -12.4 & 24.9 & & Greenish dolostone with phyllosilicates \\
\hline ALT7-345.45 & Dolomite & -5.3 & 19.5 & & Greenish dolostone with phyllosilicates \\
\hline ALT8-330.60 & Dolomite & -5.4 & 19.7 & & Greenish dolostone with phyllosilicates \\
\hline ALT1-029.80 & Calcite & -5.8 & 22.5 & & Calcite vein \\
\hline ALT3-341.80 & Calcite & -15.0 & 20.3 & & Calcite vein \\
\hline
\end{tabular}


Table 2. (Cont.)

\begin{tabular}{|c|c|c|c|c|c|}
\hline Sample & Mineral & $\begin{array}{c}\delta^{13} \mathrm{C} \\
(\% o \mathrm{~V}-\mathrm{PDB})\end{array}$ & $\begin{array}{c}\delta^{18} \mathrm{O} \\
(\% \circ \mathrm{V}-\mathrm{SMOW})\end{array}$ & ${ }^{87} \mathrm{Sr} / 86 \mathrm{Sr}$ & Observations \\
\hline \multicolumn{6}{|l|}{ Altube (Cont.) } \\
\hline $\begin{array}{l}\text { ALT6-201.40 } \\
\text { ALT6-230.50 } \\
\text { ALT6-239.50 } \\
\text { ALT6-239.50 } \\
\text { ALT7-345.45 } \\
\text { ALT1-023.60 } \\
\text { ALT1-026.80 } \\
\text { ALT1-041.10 } \\
\text { ALT1-041.10 } \\
\text { ALT1-041.10 } \\
\text { ALT1-046.00 }\end{array}$ & $\begin{array}{l}\text { Calcite } \\
\text { Calcite } \\
\text { Calcite } \\
\text { Calcite } \\
\text { Calcite } \\
\text { Dolomite } \\
\text { Dolomite } \\
\text { Dolomite } \\
\text { Dolomite } \\
\text { Dolomite } \\
\text { Dolomite }\end{array}$ & $\begin{array}{l}-5.3 \\
-7.4 \\
-4.3 \\
-6.7 \\
-3.9 \\
-6.0 \\
-4.3 \\
-4.3 \\
-1.2 \\
1.4 \\
-5.1\end{array}$ & $\begin{array}{l}19.0 \\
19.7 \\
18.5 \\
18.5 \\
18.4 \\
21.3 \\
20.2 \\
20.9 \\
20.3 \\
20.6 \\
21.1\end{array}$ & & $\begin{array}{l}\text { Calcite vein } \\
\text { Calcite vein } \\
\text { Calcite vein } \\
\text { Calcite vein } \\
\text { Calcite vein } \\
\text { Dolomite vein } \\
\text { Dolomite vein } \\
\text { Dolomite vein } \\
\text { Dolomite vein } \\
\text { Dolomite vein } \\
\text { Dolomite vein }\end{array}$ \\
\hline \multicolumn{6}{|c|}{ Ore-related carbonates } \\
\hline $\begin{array}{l}\text { ALT1-110.70 } \\
\text { ALT1-134.50 } \\
\text { ALT2-172.20 } \\
\text { ALT2-180.10 } \\
\text { ALT2-193.50 } \\
\text { ALT3-035.20 } \\
\text { ALT3-036.70 } \\
\text { ALT3-040.90 } \\
\text { ALT5-116.00 } \\
\text { ALT5-126.00 } \\
\text { ALT6-144.00 } \\
\text { ALT6-145.30 } \\
\text { ALT6-194.00 } \\
\text { ALT6-196.90 } \\
\text { ALT6-198.50 } \\
\text { ALT7-233.20 } \\
\text { ALT7-233.20 } \\
\text { ALT7-307.50 } \\
\text { ALT9-175.60 } \\
\text { ALT9-202.80 } \\
\text { ALT1-134.50 } \\
\text { ALT2-186.60 } \\
\text { ALT3-036.70 } \\
\text { ALT3-336.80 } \\
\text { ALT6-194.00 } \\
\text { ALT6-209.00 } \\
\text { ALT6-209.00 } \\
\text { ALT6-209.00 } \\
\text { ALT7-276.20 } \\
\text { ALT1-134.50 } \\
\text { ALT3-040.90 } \\
\text { ALT5-116.00 } \\
\text { ALT6-144.00 } \\
\text { ALT6-224.00 } \\
\text { ALT6-224.00 } \\
\text { ALT7-312.75 }-313.25 \\
\text { ALT5-175.60 }\end{array}$ & $\begin{array}{l}\text { Calcite } \\
\text { Calcite } \\
\text { Calcite } \\
\text { Calcite } \\
\text { Calcite } \\
\text { Calcite } \\
\text { Calcite } \\
\text { Calcite } \\
\text { Calcite } \\
\text { Calcite } \\
\text { Calcite } \\
\text { Calcite } \\
\text { Calcite } \\
\text { Calcite } \\
\text { Calcite } \\
\text { Calcite } \\
\text { Calcite } \\
\text { Calcite } \\
\text { Calcite } \\
\text { Calcite } \\
\text { Calcite } \\
\text { Calcite } \\
\text { Calcite } \\
\text { Calcite } \\
\text { Calcite } \\
\text { Calcite } \\
\text { Calcite } \\
\text { Calcite } \\
\text { Calcite } \\
\text { Dolomite } \\
\text { Dolomite } \\
\text { Dolomite } \\
\text { Dolomite } \\
\text { Dolomite } \\
\text { Dolomite } \\
\text { Dolomite } \\
\text { Dolomite } \\
\text { Dolomite } \\
\text { Dolomite }\end{array}$ & $\begin{array}{c}-0.2 \\
-0.3 \\
-4.9 \\
2.0 \\
2.4 \\
-0.3 \\
-0.2 \\
-0.2 \\
2.2 \\
-0.2 \\
0.2 \\
0.5 \\
-1.3 \\
-1.2 \\
0.8 \\
2.1 \\
2.4 \\
-1.5 \\
1.2 \\
0.4 \\
-0.6 \\
-4.7 \\
1.8 \\
-4.8 \\
-4.5 \\
-1.6 \\
-0.4 \\
-5.4 \\
-3.5 \\
-0.5 \\
-0.9 \\
3.5 \\
0.1 \\
-3.4 \\
0.2 \\
-1.4 \\
0.2\end{array}$ & $\begin{array}{l}19.0 \\
18.0 \\
18.5 \\
17.4 \\
17.3 \\
18.9 \\
20.1 \\
19.1 \\
18.4 \\
18.5 \\
18.9 \\
18.7 \\
18.8 \\
18.2 \\
18.5 \\
18.0 \\
17.5 \\
17.9 \\
18.9 \\
18.5 \\
18.8 \\
20.1 \\
22.2 \\
17.5 \\
20.3 \\
17.7 \\
17.1 \\
19.2 \\
16.6 \\
20.0 \\
17.6 \\
19.6 \\
18.4 \\
19.6 \\
19.5 \\
19.5 \\
19.3 \\
19.8 \\
19.8\end{array}$ & 0.71202 & $\begin{array}{l}\text { Cal I, vein } \\
\text { Cal I, vein } \\
\text { Cal I, vein } \\
\text { Cal I, vein } \\
\text { Cal I, vein } \\
\text { Cal I, vein } \\
\text { Cal I, vein } \\
\text { Cal I, vein } \\
\text { Cal I, vein } \\
\text { Cal I, vein } \\
\text { Cal I, vein } \\
\text { Cal I, vein } \\
\text { Cal I, vein } \\
\text { Cal I, vein } \\
\text { Cal I, vein } \\
\text { Cal I, vein } \\
\text { Cal I, vein } \\
\text { Cal I, vein } \\
\text { Cal I, vein } \\
\text { Cal I, vein } \\
\text { Cal II, veinlet } \\
\text { Cal II, geode } \\
\text { Cal II, veinlet } \\
\text { Cal II, geode } \\
\text { Cal II, geode } \\
\text { Cal II, geode } \\
\text { Cal II, geode } \\
\text { Cal II, geode } \\
\text { Cal II, veinlet } \\
\text { Dol III, vein } \\
\text { Dol III, vein } \\
\text { Dol III, vein } \\
\text { Dol III, vein } \\
\text { Dol III, vein, center } \\
\text { Dol III, vein, border } \\
\text { Dol III, vein } \\
\text { Dol III, vein } \\
\text { Dol III, vein } \\
\text { Dol III, vein }\end{array}$ \\
\hline \multicolumn{6}{|l|}{$\underline{\text { Iturlum }}$} \\
\hline $\begin{array}{l}\text { DM-02-01 } \\
\text { It-16-04 }\end{array}$ & $\begin{array}{l}\text { Dolomite } \\
\text { Dolomite }\end{array}$ & $\begin{array}{c}2.2 \\
-12.6\end{array}$ & $\begin{array}{l}28.0 \\
24.4\end{array}$ & & $\begin{array}{l}\text { Breccia clast } \\
\text { Gray dolostone }\end{array}$ \\
\hline \multicolumn{6}{|c|}{ Ore-related carbonates } \\
\hline $\begin{array}{l}\text { DM-02-01 } \\
\text { DM-02-01 } \\
\text { DM-02-01 } \\
\text { DM-02-01 } \\
\text { DM-02-02 } \\
\text { It-16-01 }\end{array}$ & $\begin{array}{l}\text { Dolomite } \\
\text { Dolomite } \\
\text { Dolomite } \\
\text { Dolomite } \\
\text { Dolomite } \\
\text { Dolomite }\end{array}$ & $\begin{array}{l}-1.8 \\
-1.7 \\
-3.3 \\
-1.7 \\
-1.4 \\
-1.3\end{array}$ & $\begin{array}{l}24.4 \\
23.8 \\
24.6 \\
22.7 \\
24.4 \\
25.0\end{array}$ & & $\begin{array}{l}\text { Dol II, replacing barite } \\
\text { Dol II, replacing barite } \\
\text { Dol II, rim on barite } \\
\text { Dol II, rim on barite } \\
\text { Dol II, replacing barite } \\
\text { Dol II, vein }\end{array}$ \\
\hline
\end{tabular}


Table 2. (Cont.)

\begin{tabular}{|c|c|c|c|c|c|}
\hline Sample & Mineral & $\begin{array}{c}\delta^{13} \mathrm{C} \\
(\% o \mathrm{~V}-\mathrm{PDB})\end{array}$ & $\begin{array}{c}\delta^{18} \mathrm{O} \\
(\% o \mathrm{~V}-\mathrm{SMOW})\end{array}$ & ${ }^{87} \mathrm{Sr} /{ }^{86} \mathrm{Sr}$ & Observations \\
\hline \multicolumn{6}{|l|}{ Jugo } \\
\hline \multicolumn{6}{|l|}{ Host rock } \\
\hline $\mathrm{Ju}-2$ & Calcite & 1.6 & 26.7 & & Carbonate nodule, Valmaseda Fm. (anoxic level) \\
\hline $\mathrm{FV}-2 \mathrm{~A}$ & Calcite & 0.1 & 21.2 & & Reefal bar, Valmaseda Fm. \\
\hline $\mathrm{FV}-2 \mathrm{~B}$ & Calcite & -1.5 & 22.6 & & Reefal bar, Valmaseda Fm. \\
\hline \multicolumn{6}{|l|}{ CTZ } \\
\hline DM-03-01 & Calcite & -7.1 & 23.8 & & Cal I, veinlet \\
\hline DM-03-01 & Calcite & -11.3 & 24.4 & & Cal I, veinlet \\
\hline DM-03-01 & Calcite & -8.2 & 23.8 & & Cal I, veinlet \\
\hline DM-03-01 & Calcite & -6.9 & 25.2 & & Cal I, veinlet \\
\hline DM-03-02 & Calcite & -10.3 & 24.9 & \multirow[t]{20}{*}{0.70986} & Cal I, veinlet \\
\hline DM-03-02 & Calcite & -8.1 & 25.3 & & Cal I, veinlet \\
\hline DM-03-01 & Dolomite & 0.1 & 27.9 & & Breccia clast \\
\hline DM-03-02 & Dolomite & -5.4 & 27.8 & & Breccia clast \\
\hline DM-03-03 & Dolomite & -2.6 & 27.6 & & Breccia clast \\
\hline DM-03-03 & Dolomite & -1.2 & 28.2 & & Breccia clast \\
\hline $\mathrm{Ju}-16-02$ & Dolomite & 0.4 & 27.5 & & Breccia clast \\
\hline Ju-16-03 & Dolomite & -0.2 & 28.7 & & Breccia clast \\
\hline Ju-16-02 & Dolomite & -7.8 & 24.6 & & Breccia cement \\
\hline Ju-16-06 & Dolomite & -20.5 & 24.6 & & Breccia cement \\
\hline Ju-16-04 & Dolomite & -14.0 & 24.7 & & Greenish dolostone with phyllosilicates \\
\hline $\mathrm{Ju}-16-07 \mathrm{a}$ & Dolomite & -14.5 & 24.4 & & Zebra dolostone, dark gray band \\
\hline Ju-16-07a & Dolomite & -16.7 & 24.8 & & Zebra dolostone, white band \\
\hline $\mathrm{Ju}-16-07 \mathrm{~b}$ & Dolomite & -9.7 & 24.3 & & Zebra dolostone, dark gray band \\
\hline $\mathrm{Ju}-16-07 \mathrm{~b}$ & Dolomite & -10.0 & 24.7 & & Zebra dolostone, white band \\
\hline $\mathrm{Ju}-16-08$ & Dolomite & -14.3 & 24.9 & & Zebra dolostone, dark gray band \\
\hline $\mathrm{Ju}-16-08$ & Dolomite & -11.2 & 24.7 & & Zebra dolostone, white band \\
\hline $\mathrm{Ju}-16-09$ & Dolomite & -10.5 & 25.0 & & Greenish dolostone \\
\hline $\mathrm{Ju}-16-09$ & Dolomite & -13.3 & 24.7 & & Zebra dolostone, dark gray band \\
\hline $\mathrm{Ju}-16-09$ & Dolomite & -13.4 & 24.4 & & Zebra dolostone, white band \\
\hline \multicolumn{6}{|c|}{ Ore-related carbonates } \\
\hline DM-03-04 & Calcite & -7.9 & 21.4 & \multirow{19}{*}{0.71116} & Cal I, vein \\
\hline DM-03-04 & Calcite & -6.5 & 21.4 & & Cal I, vein \\
\hline DM-03-05 & Calcite & -1.1 & 20.8 & & Cal I, vein \\
\hline DM-03-04 & Dolomite & 1.1 & 24.1 & & Dol I, vein \\
\hline DM-03-04 & Dolomite & 2.2 & 23.4 & & Dol I, vein \\
\hline DM-03-04 & Dolomite & 1.7 & 23.5 & & Dol I, vein \\
\hline DM-03-05 & Dolomite & 1.2 & 21.3 & & Dol I, replaced by barite \\
\hline DM-03-01 & Dolomite & -5.1 & 22.7 & & Dol II, breccia cement \\
\hline DM-03-01 & Dolomite & -7.5 & 24.1 & & Dol II, breccia cement \\
\hline DM-03-02 & Dolomite & -6.1 & 24.5 & & Dol II, breccia cement \\
\hline DM-03-03 & Dolomite & -6.0 & 22.6 & & Dol II, breccia cement \\
\hline DM-03-02 & Dolomite & -5.4 & 23.9 & & Dol III, breccia cement \\
\hline DM-03-03 & Dolomite & -10.0 & 22.4 & & Dol III, breccia cement \\
\hline DM-03-03 & Dolomite & -5.9 & 22.7 & & Dol III, breccia cement \\
\hline DM-03-03 & Dolomite & -7.7 & 22.6 & & Dol III, breccia cement \\
\hline DM-03-03 & Dolomite & -7.4 & 22.5 & & Dol III, engulfed in galena \\
\hline DM-03-04 & Dolomite & -8.8 & 24.5 & & Dol III, vein \\
\hline DM-03-03 & Dolomite & -12.3 & 23.6 & & Dol IV, veinlets crosscutting sphalerite and dol III \\
\hline DM-03-03 & Dolomite & -12.1 & 23.5 & & Dol IV, veinlets crosscutting sphalerite and dol III \\
\hline \multicolumn{6}{|c|}{$\underline{\text { Mina de Vila }}$} \\
\hline \multicolumn{6}{|c|}{ Ore-related carbonates } \\
\hline DM-04-02 & Calcite & -4.4 & 19.6 & & Cal II, vein \\
\hline DM-04-02 & Dolomite & 1.4 & 21.3 & & Gray dol III, vein \\
\hline DM-04-02 & Dolomite & -0.5 & 20.4 & & White dol III, vein \\
\hline \multicolumn{6}{|l|}{ Aperregui } \\
\hline \multicolumn{6}{|l|}{ Host rock } \\
\hline FV-16 & Calcite & 1.2 & 24.2 & & Replacive diagenetic cement in Valmaseda Fm. \\
\hline \multicolumn{6}{|l|}{ CTZ } \\
\hline Ap-16-02 & Dolomite & -4.7 & 26.6 & & Black dolostone \\
\hline Ap-16-03 & Dolomite & -10.4 & 23.8 & & Black dolostone \\
\hline DM-05-01 & Dolomite & -1.0 & 28.2 & & Breccia clast \\
\hline DM-05-04 & Dolomite & -3.8 & 27.0 & & Breccia clast \\
\hline
\end{tabular}


Table 2. (Cont.)

\begin{tabular}{|c|c|c|c|c|c|}
\hline Sample & Mineral & $\begin{array}{c}\delta^{13} \mathrm{C} \\
(\% \circ \mathrm{V}-\mathrm{PDB})\end{array}$ & $\begin{array}{c}\delta^{18} \mathrm{O} \\
(\% \circ \mathrm{V}-\mathrm{SMOW})\end{array}$ & ${ }^{87} \mathrm{Sr} / 86 \mathrm{Sr}$ & Observations \\
\hline \multicolumn{6}{|c|}{$\begin{array}{l}\text { Aperregui (Cont.) } \\
\text { CTZ }\end{array}$} \\
\hline Ap-16-01 & Dolomite & -0.7 & 28.6 & & Breccia clast \\
\hline \multicolumn{6}{|c|}{ Ore-related carbonates } \\
\hline $\begin{array}{l}\text { Ap-16-01 } \\
\text { DM-05-01 } \\
\text { DM-05-01 } \\
\text { DM-05-04 } \\
\text { DM-05-01 } \\
\text { DM-05-01 } \\
\text { DM-05-04 } \\
\text { DM-05-04 } \\
\text { DM-05-01 } \\
\text { DM-05-01 } \\
\text { DM-05-01 } \\
\text { DM-05-01 }\end{array}$ & $\begin{array}{l}\text { Dolomite } \\
\text { Dolomite } \\
\text { Dolomite } \\
\text { Dolomite } \\
\text { Dolomite } \\
\text { Dolomite } \\
\text { Dolomite } \\
\text { Dolomite } \\
\text { Dolomite } \\
\text { Dolomite } \\
\text { Dolomite } \\
\text { Dolomite }\end{array}$ & $\begin{array}{l}-5.1 \\
-4.4 \\
-4.6 \\
-4.9 \\
-9.2 \\
-8.6 \\
-7.7 \\
-8.7 \\
-12.5 \\
-13.7 \\
-12.4 \\
-12.3\end{array}$ & $\begin{array}{l}22.5 \\
22.8 \\
22.2 \\
21.1 \\
22.8 \\
22.1 \\
22.3 \\
22.3 \\
23.0 \\
22.5 \\
23.1 \\
23.1\end{array}$ & & $\begin{array}{l}\text { Dol II, breccia cement } \\
\text { Dol II, breccia cement } \\
\text { Dol II, breccia cement } \\
\text { Dol II, breccia cement } \\
\text { Dol III, breccia cement } \\
\text { Dol III, breccia cement } \\
\text { Dol III, breccia cement } \\
\text { Dol III, breccia cement } \\
\text { Dol IV veinlets crosscutting sphalerite and dol III } \\
\text { Dol IV veinlets crosscutting sphalerite and dol III } \\
\text { Dol IV veinlets crosscutting sphalerite and dol III } \\
\text { Dol IV veinlets crosscutting sphalerite and dol III }\end{array}$ \\
\hline \multicolumn{6}{|l|}{ Beluntza } \\
\hline $\begin{array}{l}\text { BEL1-099.85 } \\
\text { BEL1-218.65 } \\
\text { BEL1-330.50 } \\
\text { DM-06-02 } \\
\text { Gu-3 }\end{array}$ & $\begin{array}{l}\text { Calcite } \\
\text { Calcite } \\
\text { Calcite } \\
\text { Dolomite } \\
\text { Calcite }\end{array}$ & $\begin{array}{l}2.6 \\
2.3 \\
1.3 \\
0.7 \\
2.8\end{array}$ & $\begin{array}{l}24.7 \\
23.0 \\
23.5 \\
24.9 \\
26.0\end{array}$ & & $\begin{array}{l}\text { Cenomanian limestone } \\
\text { Cenomanian limestone } \\
\text { Cenomanian limestone } \\
\text { Dolomitized Cenomanian limestone } \\
\text { Cenomanian limestone }\end{array}$ \\
\hline \multicolumn{6}{|c|}{ Ore-related carbonates } \\
\hline $\begin{array}{l}\text { DM-06-01 } \\
\text { DM-06-01 } \\
\text { DM-06-01 } \\
\text { DM-06-01 } \\
\text { DM-06-02 } \\
\text { DM-06-02 }\end{array}$ & $\begin{array}{l}\text { Calcite } \\
\text { Calcite } \\
\text { Calcite } \\
\text { Calcite } \\
\text { Calcite } \\
\text { Calcite }\end{array}$ & $\begin{array}{c}-1.7 \\
-1.1 \\
0.5 \\
-1.6 \\
-2.3 \\
-3.0\end{array}$ & $\begin{array}{l}18.3 \\
21.1 \\
22.3 \\
22.1 \\
16.1 \\
21.8\end{array}$ & & $\begin{array}{l}\text { Cal I, vein } \\
\text { Cal I, vein } \\
\text { Cal I, vein } \\
\text { Cal I, vein } \\
\text { Cal I, vein } \\
\text { Cal I, vein }\end{array}$ \\
\hline$\frac{\text { Orduña diapir }}{\text { Artomaña }}$ & & & & & \\
\hline $\begin{array}{l}\text { DO-01-01 } \\
\text { DO-01-03 } \\
\text { DO-01-04 }\end{array}$ & $\begin{array}{l}\text { Calcite } \\
\text { Calcite } \\
\text { Calcite }\end{array}$ & $\begin{array}{l}1.1 \\
0.6 \\
0.5\end{array}$ & $\begin{array}{l}27.3 \\
27.3 \\
27.3\end{array}$ & & $\begin{array}{l}\text { Turonian limestone clasts in breccias with bitumen matrix } \\
\text { Turonian limestone clasts in breccias with bitumen matrix } \\
\text { Turonian limestone clasts in breccias with bitumen matrix }\end{array}$ \\
\hline \multicolumn{6}{|c|}{ La Antigua } \\
\hline $\begin{array}{l}\text { DO-02-02 } \\
\text { DO-02-04 } \\
\text { DO-02-04 } \\
\text { DO-02-04 } \\
\text { DO-02-05 } \\
\text { DO-02-06 } \\
\text { DO-02-07 } \\
\text { DO-02-04 }\end{array}$ & $\begin{array}{l}\text { Calcite } \\
\text { Calcite } \\
\text { Calcite } \\
\text { Calcite } \\
\text { Calcite } \\
\text { Calcite } \\
\text { Calcite } \\
\text { Dolomite }\end{array}$ & $\begin{array}{c}1.7 \\
-1.3 \\
-0.6 \\
1.4 \\
1.8 \\
1.7 \\
1.9 \\
0.1\end{array}$ & $\begin{array}{l}24.9 \\
24.2 \\
23.7 \\
24.7 \\
25.1 \\
25.0 \\
25.1 \\
24.3\end{array}$ & & $\begin{array}{l}\text { Cal I, vein } \\
\text { Cal I, vein } \\
\text { Cal I, vein } \\
\text { Cal I, vein } \\
\text { Cal I, vein } \\
\text { Cal I, vein } \\
\text { Cal I, vein } \\
\text { Dol III, vein }\end{array}$ \\
\hline \multicolumn{6}{|l|}{ Montaleón } \\
\hline $\begin{array}{l}\text { DO-03-00 } \\
\text { DO-03-02 } \\
\text { DO-03-03 } \\
\text { DO-03-04 } \\
\text { DO-03-05 } \\
\text { DO-03-06 } \\
\text { DO-03-12 }\end{array}$ & $\begin{array}{l}\text { Dolomite } \\
\text { Dolomite } \\
\text { Dolomite } \\
\text { Dolomite } \\
\text { Dolomite } \\
\text { Dolomite } \\
\text { Dolomite }\end{array}$ & $\begin{array}{c}-0.8 \\
-0.1 \\
0.2 \\
-1 \\
-2.2 \\
-0.6 \\
0.7\end{array}$ & $\begin{array}{l}23.0 \\
23.9 \\
24.5 \\
24.7 \\
24.3 \\
23.7 \\
23.7\end{array}$ & & $\begin{array}{l}\text { Dolomitized Turonian limestone } \\
\text { Dolomitized Turonian limestone } \\
\text { Dolomitized Turonian limestone } \\
\text { Dolomitized Turonian limestone } \\
\text { Dolomitized Turonian limestone } \\
\text { Dolomitized Turonian limestone } \\
\text { Dolomitized Turonian limestone }\end{array}$ \\
\hline \multicolumn{6}{|c|}{ Ore-related carbonates } \\
\hline $\begin{array}{l}\text { DO-03-00 } \\
\text { DO-03-00 } \\
\text { DO-03-01 } \\
\text { DO-03-00 }\end{array}$ & $\begin{array}{l}\text { Calcite } \\
\text { Calcite } \\
\text { Calcite } \\
\text { Dolomite }\end{array}$ & $\begin{array}{l}-1.1 \\
-0.9 \\
-3.6 \\
-1.6\end{array}$ & $\begin{array}{l}22.1 \\
21.6 \\
23.2 \\
24.1\end{array}$ & $\begin{array}{l}0.70949 \\
0.70863\end{array}$ & $\begin{array}{l}\text { Cal I, vein } \\
\text { Cal I, vein } \\
\text { Cal I, vein } \\
\text { Dol III, veinlets }\end{array}$ \\
\hline
\end{tabular}


Table 2. (Cont.)

\begin{tabular}{|c|c|c|c|c|c|}
\hline Sample & Mineral & $\begin{array}{c}\delta^{13} \mathrm{C} \\
(\% o \mathrm{~V}-\mathrm{PDB})\end{array}$ & $\begin{array}{c}\delta^{18} \mathrm{O} \\
(\% o \mathrm{~V}-\mathrm{SMOW})\end{array}$ & ${ }^{87} \mathrm{Sr} / 86 \mathrm{Sr}$ & Observations \\
\hline \multicolumn{6}{|c|}{ Montaleón (Cont.) } \\
\hline \multicolumn{6}{|c|}{ Ore-related carbonates } \\
\hline DO-03-00 & Dolomite & -1.6 & 24.0 & & Dol III, veinlets \\
\hline DO-03-00 & Dolomite & -1.6 & 24.0 & & Dol III, vein \\
\hline DO-03-00 & Dolomite & -1.7 & 24.0 & & Dol III, vein \\
\hline DO-03-00 & Dolomite & -1.7 & 24.5 & & Dol III, vein \\
\hline DO-03-01 & Dolomite & 0.6 & 25.7 & & Dol III, vein \\
\hline DO-03-01 & Dolomite & 0.8 & 25.7 & & Dol III, vein \\
\hline DO-03-02 & Dolomite & -4.8 & 24.0 & & Dol III, vein \\
\hline DO-03-02 & Dolomite & -0.6 & 25.2 & & Dol III, vein \\
\hline DO-03-03 & Dolomite & -4.9 & 25.1 & & Dol III, vein \\
\hline DO-03-04 & Dolomite & 0.1 & 23.3 & & Dol III, replacing disseminated sphalerite \\
\hline DO-03-05 & Dolomite & -1.7 & 25.4 & & Dol III, vein \\
\hline DO-03-05 & Dolomite & -2.1 & 25.2 & & Dol III, vein \\
\hline DO-03-05 & Dolomite & -2.3 & 25.0 & & Dol III, replacing disseminated sphalerite \\
\hline DO-03-05 & Dolomite & -1.2 & 25.5 & & Dol III, replacing disseminated sphalerite \\
\hline DO-03-05 & Dolomite & -1.6 & 25.3 & & Dol III, replacing disseminated sphalerite \\
\hline DO-03-06 & Dolomite & -0.7 & 22.2 & & Dol III, vein \\
\hline DO-03-08 & Dolomite & -3.0 & 24.3 & & Dol III, vein \\
\hline DO-03-09 & Dolomite & -1.6 & 24.7 & & Dol III, vein \\
\hline DO-03-09 & Dolomite & 1.0 & 25.9 & & Dol III, vein \\
\hline DO-03-09 & Dolomite & 1.0 & 25.6 & & Dol III, vein \\
\hline DO-03-09 & Dolomite & -4.5 & 24.4 & & Dol III, vein \\
\hline DO-03-09 & Dolomite & -2.2 & 25.4 & & Dol III, vein \\
\hline DO-03-10 & Dolomite & -4.6 & 23.8 & & Dol III, vein \\
\hline DO-03-10 & Dolomite & -4.7 & 23.7 & & Dol III, vein \\
\hline DO-03-12 & Dolomite & -4.1 & 23.5 & & Dol III, vein \\
\hline DO-03-12 & Dolomite & -0.5 & 23.4 & & Dol III, engulfed in galena \\
\hline DO-03-00 & Dolomite & -1.6 & 26.7 & & Dol IV, veinlets crosscutting sulfides and dol III \\
\hline \multicolumn{6}{|l|}{ Paúl } \\
\hline \multicolumn{6}{|l|}{$\overline{\text { Host rock }}$} \\
\hline Paul1-19.50 & Calcite & 2.4 & 25.8 & & Turonian marly limestones \\
\hline Paul1-19.50 & Calcite & 2.4 & 25.7 & & Turonian marly limestones \\
\hline Paul2-20.30 & Calcite & 2.5 & 26.3 & & Turonian marly limestones \\
\hline Paul2-20.30 & Calcite & 2.5 & 26.0 & & Turonian marly limestones \\
\hline \multicolumn{6}{|c|}{ Ore-related carbonates } \\
\hline Paul1-06.00 & Calcite & 2.0 & 24.9 & & Cal I, vein \\
\hline Paul1-06.00 & Calcite & 2.1 & 25.0 & & Cal I, vein \\
\hline Paul2-12.20 & Calcite & 2.0 & 24.9 & & Cal I, vein \\
\hline Paul2-12.20 & Calcite & 1.8 & 24.5 & & Cal I, vein \\
\hline Paul2-12.70 & Calcite & 1.8 & 24.3 & & Cal I, vein \\
\hline Paul2-12.70 & Calcite & 1.8 & 24.4 & & Cal I, vein \\
\hline Paul2-12.70 & Calcite & 0.7 & 24.1 & & Cal I, vein \\
\hline Paul2-14.70 & Calcite & 2.0 & 25.0 & & Cal I, vein \\
\hline Paul2-14.70 & Calcite & 2.0 & 24.4 & & Cal I, vein \\
\hline Paul2-14.70 & Calcite & 2.0 & 25.1 & & Cal I, vein \\
\hline Paul-2A & Calcite & 1.3 & 24.1 & & Cal I, vein \\
\hline Paul-2A & Calcite & 1.2 & 24.2 & & Cal I, vein \\
\hline Paul-2B & Calcite & 1.5 & 24.8 & & Cal I, engulfed in sulfides \\
\hline Paul-2C & Calcite & 1.0 & 23.7 & & Cal I, vein \\
\hline Paul2-13.80 & Calcite & 1.7 & 21.7 & & Cal II, veinlet crosscutting sulfides, dol III and cal I \\
\hline DO-04-01 & Dolomite & 3.0 & 26.9 & 0.70834 & Dol III, engulfed in sulfides \\
\hline DO-04-02 & Dolomite & 3.2 & 27.4 & & Dol III, engulfed in sulfides \\
\hline DO-04-02 & Dolomite & 3.2 & 27.4 & & Dol III, engulfed in sulfides \\
\hline DO-04-02 & Dolomite & 2.9 & 26.8 & & Dol III, engulfed in sulfides \\
\hline Paul1-06.00 & Dolomite & 2.3 & 27.1 & 0.70801 & Dol III, vein \\
\hline Paul1-06.00 & Dolomite & 2.8 & 26.4 & & Dol III, vein \\
\hline Paul2-12.70 & Dolomite & 3.0 & 26.9 & & Dol III, vein \\
\hline Paul2-13.80 & Dolomite & 2.9 & 27.0 & & Dol III, vein \\
\hline Paul2-13.80 & Dolomite & 2.9 & 26.9 & & Dol III, vein \\
\hline Paul2-14.70 & Dolomite & 2.8 & 26.4 & & Dol III, vein \\
\hline Paul-2A & Dolomite & 3.0 & 26.6 & & Dol III, vein \\
\hline Paul-2B & Dolomite & 3.1 & 26.7 & & Dol III, engulfed in sulfides \\
\hline
\end{tabular}

Abbreviations: CTZ = carbonate transition zone, V-PDB = Vienna Pee Dee Belemnite, V-SMOW = Vienna-standard mean ocean water 


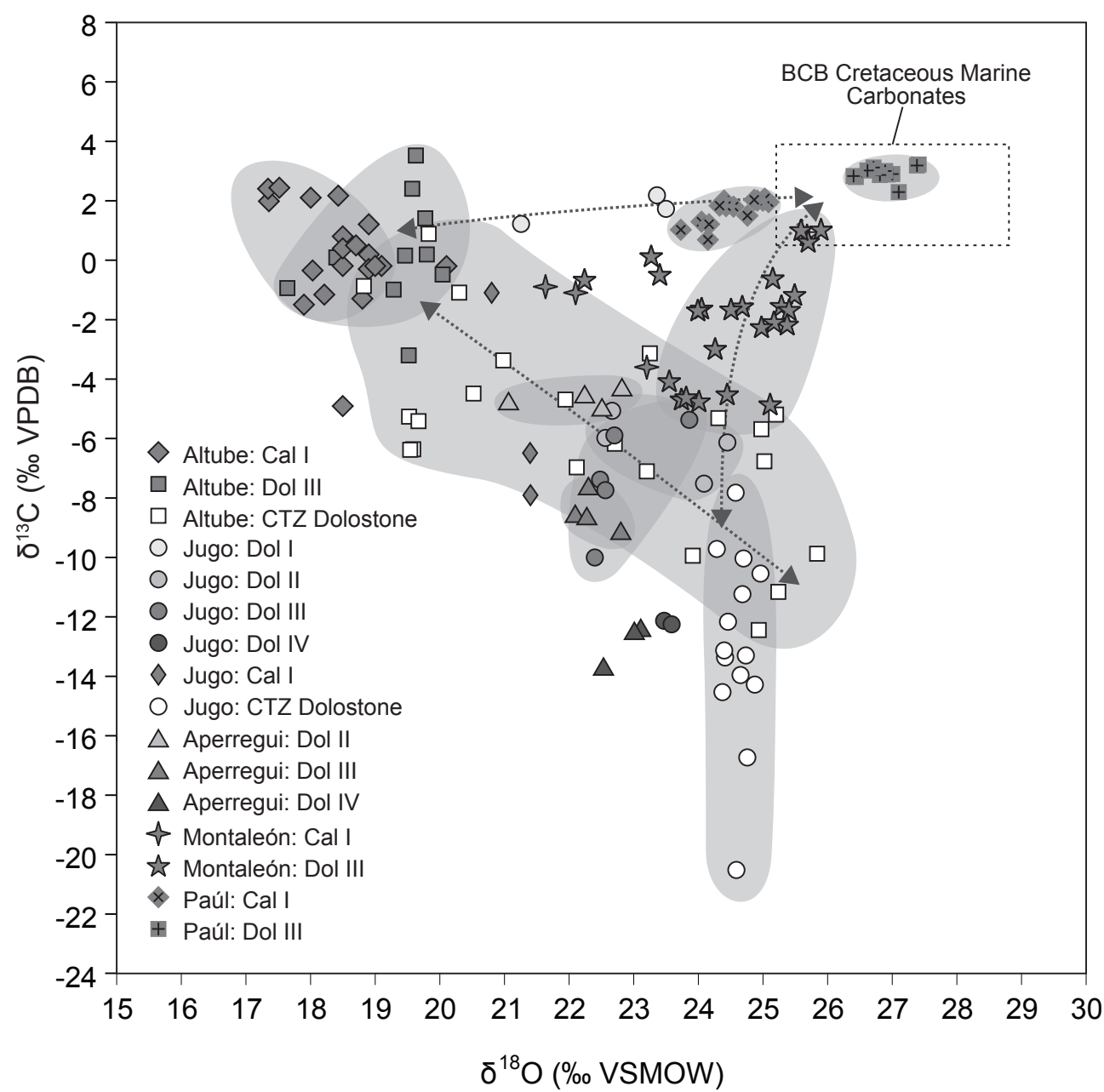

Fig. 8. $\delta^{13} \mathrm{C} / \delta^{18} \mathrm{O}$ plot of carbonates from mineralization and enclosing rocks around the Murguía and Orduña diapirs. Double arrows show the three groups defined in the text: samples with large $\delta^{18} \mathrm{O}$ and small $\delta^{13} \mathrm{C}$ differences (horizontal distribution: Altube, Paúl, Montaleón), samples with large $\delta^{13} \mathrm{C}$ and small $\delta^{18} \mathrm{O}$ differences (vertical distribution: Aperregui, Jugo, Montaleón), and samples varying from low $\delta^{13} \mathrm{C}$ and high $\delta^{18} \mathrm{O}$ to high $\delta^{13} \mathrm{C}$ and low $\delta^{18} \mathrm{O}$ (diagonal distribution: carbonate transition zone at Altube). See interpretation in the text. Data for Cretaceous carbonates of the Basque-Cantabrian basin are from Bustillo and Ordoñez (1995), Velasco et al. (2003), and this study. Abbreviations: BCB = Basque-Cantabrian basin, $\mathrm{CTZ}=$ carbonate transition zone, VPDB = Vienna Pee Dee Belemnite, VSMOW = Vienna standard mean ocean water.

\section{Discussion}

\section{Mineralogy and paragenesis}

$\mathrm{Zn}-\mathrm{Pb}$ sulfide deposits distributed around the Murguía and Orduña diapirs are located in radial or annular structures (carbonate transition zone) developed during the diapir emplacement. Mineralization shows a replacive character and the common presence of organic matter. Regardless of the locality and host lithology, the paragenetic sequence and textures in all deposits are similar (Fig. 5). Barite and replacive dolomite predate sulfides (sphalerite, galena, and pyrite/marcasite), which are contemporaneous with saddle dolomite. However, contemporaneity between deposits cannot be inferred from these observations. Compared to other $\mathrm{Zn}-\mathrm{Pb}$ deposits of the Basque-Cantabrian basin (e.g., Reocín; Velasco et al., 2003), the lack of botryoidal textures in sulfides from the studied deposits suggests that precipitation took place at low supersaturation and under slow growth conditions (García-Ruíz and Otálora, 2015).
Although several types of dolomite have been distinguished, they do not necessarily represent separate events, nor did they form contemporaneously. Indeed, the gradual contact between dolomite II and III suggests that they could result from a continuous process, in accordance with the selforganized dynamics dolomitization and ore-related model of Merino and Canals (2011). In this model, dolomite and ores of late pulses may partially replace ores and dolomites that formed in early growth pulses. Successive replacements released $\mathrm{CO}_{3}^{2-}, \mathrm{Mg}^{2+}, \mathrm{Zn}^{2+}$, and $\mathrm{S}^{2-}$, which are advected forward, thus promoting reprecipitation of more dolomite and/or sphalerite, therefore generating a larger deposit.

Considering the field position and mineralogy, the carbonate transition zone at the Murguía diapir is interpreted as a former caprock. This is also supported by the presence of overgrowths in tourmalines with a chemical composition related to boronrich (evaporitic) fluids (Figs. 2C, 3), pyrite pseudomorphically replacing a former platy mineral (sulfate, marcasite [?]) (Fig. $2 \mathrm{~B}$ ), and stable isotope data of carbonates (see below). 


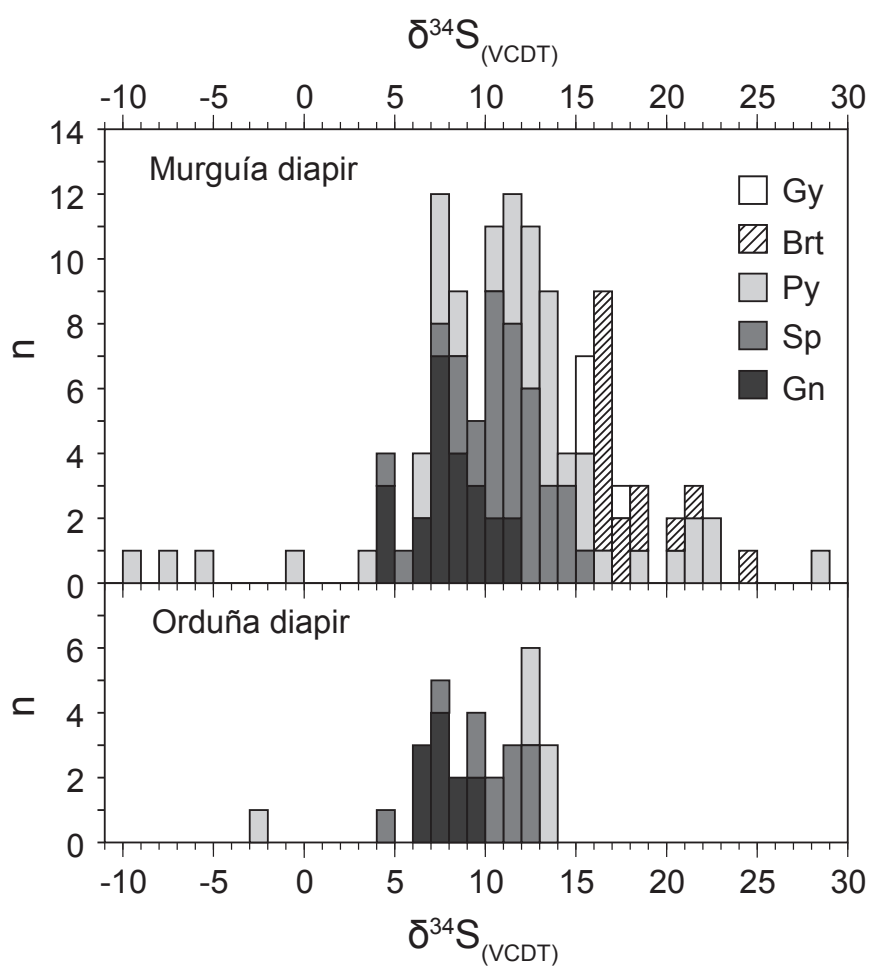

Fig. 9. $\delta^{34} \mathrm{~S}$ histograms of sulfides and sulfates from mineralization in the Murguía and Orduña diapirs. Extreme values have been omitted (see Table 3). Abbreviations: Brt = barite, $\mathrm{Gn}=$ galena, $\mathrm{Gy}=$ gypsum, $\mathrm{Py}=$ pyrite, $\mathrm{Sp}=$ sphalerite, VCDT = Vienna Canyon Diablo Troilite.

\section{Fluid inclusion, organic matter, and isotope geothermometry}

Microthermometric and crush-leach data of fluid inclusions in sphalerite, quartz, and dolomite from the studied deposits were published by Grandia et al. (2003). According to these authors, complex polysaline $\left(\mathrm{CaCl}_{2}-\mathrm{NaCl}-\mathrm{H}_{2} \mathrm{O}\right.$ system) and hydrocarbon-bearing fluids were involved in ore formation, with salinities ranging from 10.9 to 25.5 wt $\% \mathrm{NaCl}$ equiv. From halogen data, Grandia et al. (2003) interpreted the origin of the salinity as caused by mixing between evaporated seawater and brines after dissolution of halite from the salt domes. Reported homogenization temperatures $\left(T_{h}\right)$ in sphalerite range from $126^{\circ}$ to $295^{\circ} \mathrm{C}$ (Altube, $144^{\circ}-295^{\circ} \mathrm{C}$; Montaleón, $175^{\circ}-204^{\circ} \mathrm{C}$; Aperregui, $150^{\circ}-202^{\circ} \mathrm{C}$; Jugo, $\left.126^{\circ}-173^{\circ} \mathrm{C}\right)$. At Paúl lower $\mathrm{T}_{\mathrm{h}}$ values were measured, from $80^{\circ}$ to $196^{\circ} \mathrm{C}$ (disseminated sulfides $80^{\circ}-118^{\circ} \mathrm{C}$; semimassive mineralization $\left.84^{\circ}-196^{\circ} \mathrm{C}\right)$.

The wide $\mathrm{T}_{\mathrm{h}}$ range on single sphalerite samples from Altube and Montaleón, reported by Grandia et al. (2003), can be related to postentrapment stretching, trapping a nonhomogeneous fluid, or temperature changes during trapping. Although all three possibilities are plausible, the heterogeneous trapping is favored here. This is supported by the presence of volatile components $\left(\mathrm{CH}_{4}\right)$ in some fluid inclusions (Grandia et al., 2003) and by the spatial relationship between organic matter and sulfides and the occurrence of degassing textures (see Fig. 6E, F). The local incorporation of different amounts of volatile components into the ore fluid, produced after in situ organic matter maturation, would affect the density of the fluid, resulting in variable $\mathrm{T}_{\mathrm{h}}$ values.

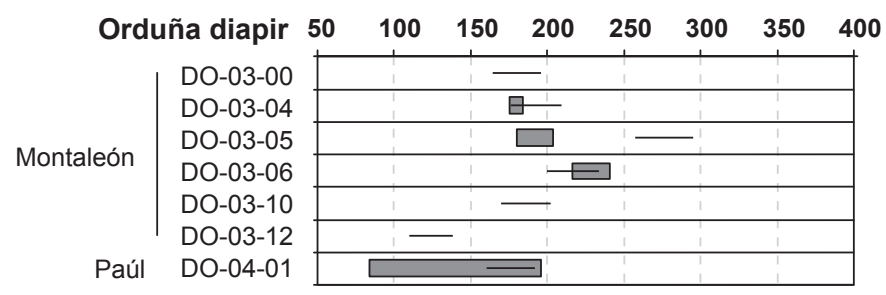

Murguía diapir

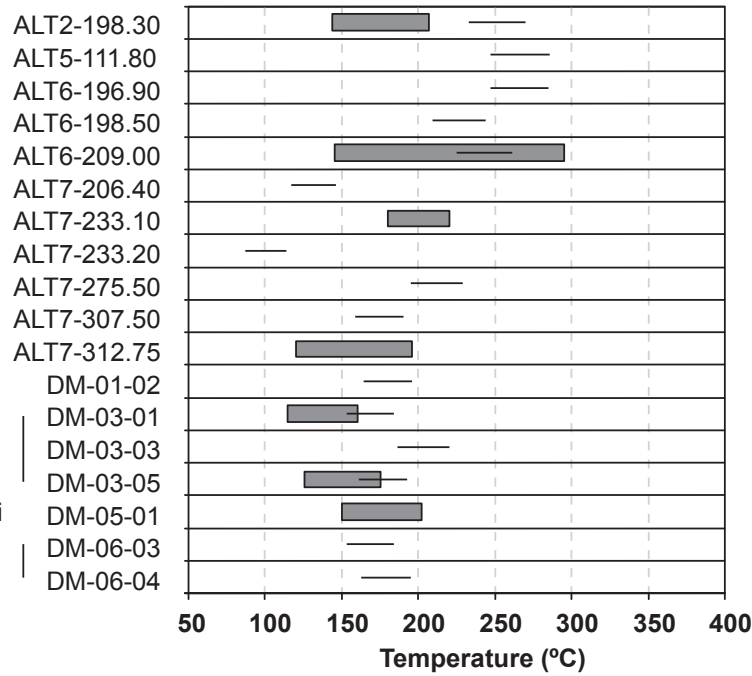

Fig. 10. Comparison between fluid inclusion homogenization temperatures ( $\mathrm{T}_{\mathrm{h}}$, solid lines) and sphalerite-galena isotope geothermometry (shaded rectangles) of mineralization around the Murguía and Orduña diapirs. Fluid inclusion data are from Grandia et al. (2003).

Sphalerite-galena pairs gave average isotopic equilibrium temperatures of $200 \pm 50^{\circ} \mathrm{C}(n=23$; Fig. 10) with 10 of them showing a narrower range $\left(178 \pm 7^{\circ} \mathrm{C}\right)$. The extreme values of the calculated temperatures could be explained by the replacement of isotopically heterogeneous pyrite by sphalerite and galena (Fig. 6C; see "Sulfur isotopes" section). We take a value $\sim 175^{\circ} \mathrm{C}$ to be representative of the isotope's equilibrium temperature. The small difference between isotopic temperatures and fluid inclusion $\mathrm{T}_{\mathrm{h}}$ values assumed here suggests that mineralization formed close to surface.

In most of the studied deposits, organic matter is overmatured, as shown by the Rock Eval and $\mathrm{BR}_{0}$ results (see Table 1). However, the large differences in these parameters over short distances within the same diapir cannot be explained by simple maturation at a regional scale. Therefore, organic matter thermal indicators point to the existence of local and different thermal anomalies around the diapirs that are probably related to the flow of hydrothermal fluids, a process widely documented to occur around salt domes (e.g., Evans et al., 1991). On the other hand, the mosaic anisotropy textures observed on some bitumen samples can be the result of a rapid heating event (Schoenherr et al., 2007) or of a syn- or postheating deformation (Fink et al., 2016).

Calculated temperatures for the bitumen isotropic samples from Altube $\left(284^{\circ}-300^{\circ} \mathrm{C}\right)$ are higher than those obtained from sulfur isotope geothermometry. Nevertheless, geothermometrical data from bitumen reflectance should be taken with caution, because compared to vitrinite, the different 
Table 3. $\delta^{34} \mathrm{~S}$ of Sulfides and Sulfates

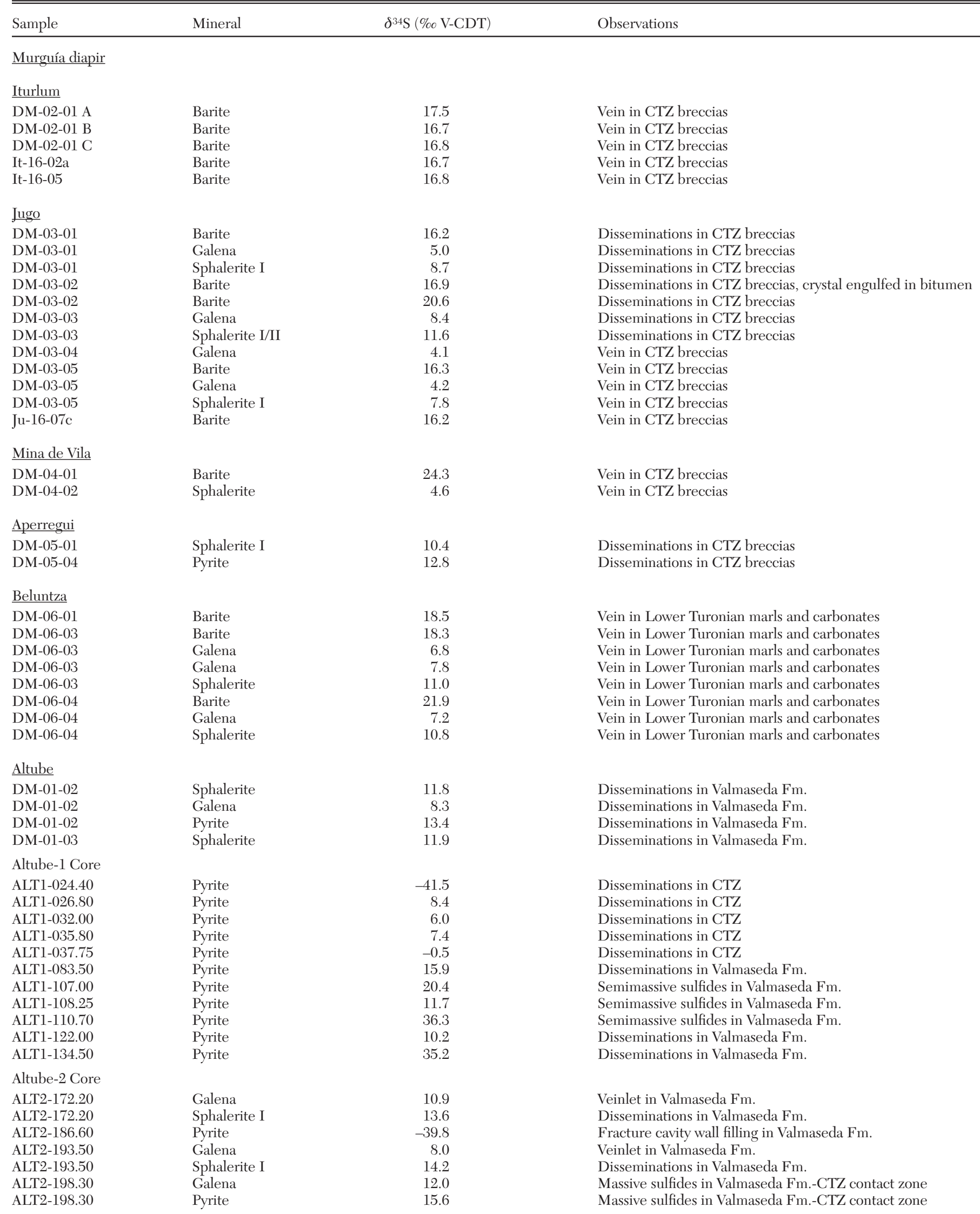


Table 3. (Cont.)

\begin{tabular}{|c|c|c|c|}
\hline Sample & Mineral & $\delta^{34} \mathrm{~S}(\% \circ \mathrm{V}-\mathrm{CDT})$ & Observations \\
\hline \multicolumn{4}{|l|}{$\begin{array}{l}\text { Altube (Cont.) } \\
\text { Altube-2 Core }\end{array}$} \\
\hline $\begin{array}{l}\text { ALT2-198.30 } \\
\text { ALT2-207.10 } \\
\text { ALT2-207.10 } \\
\text { ALT2-207.10 } \\
\text { ALT2-237.00 }\end{array}$ & $\begin{array}{l}\text { Sphalerite I } \\
\text { Sphalerite } \\
\text { Galena } \\
\text { Pyrite } \\
\text { Gypsum }\end{array}$ & $\begin{array}{r}14.6 \\
15.1 \\
7.6 \\
-9.1 \\
17.4\end{array}$ & $\begin{array}{l}\text { Massive sulfides in Valmaseda Fm.-CTZ contact zone } \\
\text { Disseminations in CTZ } \\
\text { Disseminations in CTZ } \\
\text { Disseminations in CTZ } \\
\text { Fibrous gypsum vein in CTZ }\end{array}$ \\
\hline $\begin{array}{l}\text { Altube-3 Core } \\
\text { ALT3-023.00 } \\
\text { ALT3-036.70 } \\
\text { ALT3-040.90 } \\
\text { ALT3-336.80 }\end{array}$ & $\begin{array}{l}\text { Pyrite } \\
\text { Sphalerite I } \\
\text { Sphalerite } \\
\text { Pyrite }\end{array}$ & $\begin{array}{r}11.6 \\
8.2 \\
8.4 \\
10.5\end{array}$ & $\begin{array}{l}\text { Disseminations in Valmaseda Fm. } \\
\text { Disseminations in Valmaseda Fm. } \\
\text { Disseminations in Valmaseda Fm. } \\
\text { Disseminations in CTZ }\end{array}$ \\
\hline $\begin{array}{l}\text { Altube-4 Core } \\
\text { ALT 4-142.60 }\end{array}$ & Pyrite & 11.9 & Disseminations in Valmaseda Fm. \\
\hline $\begin{array}{l}\text { Altube-5 Core } \\
\text { ALT5-108.00 } \\
\text { ALT5-111.80 } \\
\text { ALT5-111.80 } \\
\text { ALT5-111.80 } \\
\text { ALT5-116.00 } \\
\text { ALT5-126.00 }\end{array}$ & $\begin{array}{l}\text { Pyrite } \\
\text { Galena } \\
\text { Pyrite } \\
\text { Sphalerite I } \\
\text { Sphalerite } \\
\text { Sphalerite }\end{array}$ & $\begin{array}{l}12.6 \\
11.2 \\
13.8 \\
13.7 \\
13.8 \\
14.3\end{array}$ & $\begin{array}{l}\text { Disseminations in CTZ } \\
\text { Massive sulfides in Valmaseda Fm.-CTZ contact zone } \\
\text { Massive sulfides in Valmaseda Fm.-CTZ contact zone } \\
\text { Massive sulfides in Valmaseda Fm.-CTZ contact zone } \\
\text { Disseminations in CTZ } \\
\text { Disseminations in Valmaseda Fm. }\end{array}$ \\
\hline $\begin{array}{l}\text { Altube-6 Core } \\
\text { ALT6-144.00 } \\
\text { ALT6-144.70 } \\
\text { ALT6-145.30 } \\
\text { ALT6-196.90 } \\
\text { ALT6-196.90 } \\
\text { ALT6-198.00 } \\
\text { ALT6-198.50 } \\
\text { ALT6-198.50 } \\
\text { ALT6-198.50 } \\
\text { ALT6-205.80 } \\
\text { ALT6-209.00 } \\
\text { ALT6-209.00 } \\
\text { ALT6-209.00 } \\
\text { ALT6-230.50 } \\
\text { ALT6-239.50 } \\
\text { ALT6-239.50 } \\
\text { ALT6-239.50 } \\
\text { ALT6-269.40 } \\
\text { ALT6-305.45 }\end{array}$ & $\begin{array}{l}\text { Pyrite } \\
\text { Pyrite } \\
\text { Pyrite } \\
\text { Sphalerite } \\
\text { Galena } \\
\text { Pyrite } \\
\text { Galena } \\
\text { Sphalerite I/II } \\
\text { Pyrite } \\
\text { Pyrite } \\
\text { Galena } \\
\text { Sphalerite II } \\
\text { Pyrite } \\
\text { Pyrite } \\
\text { Pyrite } \\
\text { Pyrite } \\
\text { Pyrite } \\
\text { Gypsum } \\
\text { Gypsum }\end{array}$ & $\begin{array}{r}21.9 \\
22.8 \\
28.3 \\
12.0 \\
9.5 \\
18.1 \\
9.6 \\
12.5 \\
14.1 \\
3.4 \\
10.1 \\
12.8 \\
12.3 \\
8.0 \\
8.2 \\
6.6 \\
7.1 \\
15.7 \\
15.4\end{array}$ & $\begin{array}{l}\text { Disseminations in Valmaseda Fm. } \\
\text { Disseminations in Valmaseda Fm. } \\
\text { Disseminations in Valmaseda Fm. } \\
\text { Disseminations in Valmaseda Fm. } \\
\text { Disseminations in Valmaseda Fm. } \\
\text { Disseminations in Valmaseda Fm. } \\
\text { Vein in Valmaseda Fm. } \\
\text { Vein in Valmaseda Fm. } \\
\text { Vein in Valmaseda Fm. } \\
\text { Disseminations in CTZ } \\
\text { Veinlet in Valmaseda Fm. } \\
\text { Veinlet in Valmaseda Fm. } \\
\text { Veinlet in Valmaseda Fm. } \\
\text { Disseminations in CTZ } \\
\text { Disseminations in CTZ } \\
\text { Disseminations in CTZ } \\
\text { Disseminations in CTZ } \\
\text { Keuper facies } \\
\text { Keuper facies }\end{array}$ \\
\hline \multicolumn{4}{|l|}{ Altube-7 Core } \\
\hline $\begin{array}{l}\text { ALT7-204.50 } \\
\text { ALT7-206.40 } \\
\text { ALT7-206.40 } \\
\text { ALT7-206.40 } \\
\text { ALT7-206.40 } \\
\text { ALT7-207.00 } \\
\text { ALT7-207.00 } \\
\text { ALT7-210.00 } \\
\text { ALT7-210.00 } \\
\text { ALT7-231.50 } \\
\text { ALT7-231.50 } \\
\text { ALT7-233.10 } \\
\text { ALT7-233.20 } \\
\text { ALT7-233.20 } \\
\text { ALT7-233.20 } \\
\text { ALT7-233.20 } \\
\text { ALT7-233.70 } \\
\text { ALT7-233.70 } \\
\text { ALT7-275.50 } \\
\text { ALT7-275.50 } \\
\text { ALT7-276.20 } \\
\text { ALT7-307.50 } \\
\text { ALT7-307.50 }\end{array}$ & $\begin{array}{l}\text { Pyrite } \\
\text { Galena } \\
\text { Galena } \\
\text { Pyrite } \\
\text { Sphalerite I } \\
\text { Sphalerite } \\
\text { Pyrite } \\
\text { Sphalerite II } \\
\text { Pyrite } \\
\text { Galena } \\
\text { Sphalerite } \\
\text { Sphalerite II } \\
\text { Galena } \\
\text { Sphalerite I/II } \\
\text { Sphalerite I/II } \\
\text { Pyrite } \\
\text { Sphalerite II } \\
\text { Pyrite } \\
\text { Galena } \\
\text { Sphalerite I } \\
\text { Sphalerite I } \\
\text { Galena } \\
\text { Sphalerite }\end{array}$ & $\begin{array}{r}12.5 \\
6.8 \\
8.5 \\
13.6 \\
12.0 \\
12.9 \\
13.4 \\
12.0 \\
12.5 \\
9.0 \\
12.2 \\
10.4 \\
7.7 \\
9.2 \\
12.9 \\
13.3 \\
10.2 \\
7.4 \\
7.3 \\
10.4 \\
5.8 \\
7.3 \\
10.9\end{array}$ & $\begin{array}{l}\text { Disseminations in Valmaseda Fm. } \\
\text { Massive sulfides in Valmaseda Fm.-CTZ contact zone } \\
\text { Massive sulfides in Valmaseda Fm.-CTZ contact zone } \\
\text { Massive sulfides in Valmaseda Fm.-CTZ contact zone } \\
\text { Massive sulfides in Valmaseda Fm.-CTZ contact zone } \\
\text { Disseminations in Valmaseda Fm. } \\
\text { Disseminations in Valmaseda Fm. } \\
\text { Disseminations in Valmaseda Fm. } \\
\text { Disseminations in Valmaseda Fm. } \\
\text { Disseminations in Valmaseda Fm. } \\
\text { Disseminations in Valmaseda Fm. } \\
\text { Disseminations in Valmaseda Fm. } \\
\text { Vein in Valmaseda Fm. } \\
\text { Vein in Valmaseda Fm. } \\
\text { Vein in Valmaseda Fm. } \\
\text { Vein in Valmaseda Fm. } \\
\text { Disseminations in Valmaseda Fm. } \\
\text { Disseminations in Valmaseda Fm. } \\
\text { Disseminations in Valmaseda Fm. } \\
\text { Disseminations in Valmaseda Fm. } \\
\text { Disseminations in Valmaseda Fm. } \\
\text { Veinlet in Valmaseda Fm. } \\
\text { Veinlet in Valmaseda Fm. }\end{array}$ \\
\hline
\end{tabular}


Table 3. (Cont.)

\begin{tabular}{|c|c|c|c|}
\hline Sample & Mineral & $\delta^{34} \mathrm{~S}(\% \circ \mathrm{V}-\mathrm{CDT})$ & Observations \\
\hline \multicolumn{4}{|l|}{$\begin{array}{l}\text { Altube (Cont.) } \\
\text { Altube-7 Core }\end{array}$} \\
\hline $\begin{array}{l}\text { ALT7-312.75 } \\
\text { ALT7-313.25 } \\
\text { ALT7-313.25 }\end{array}$ & $\begin{array}{l}\text { Pyrite } \\
\text { Galena } \\
\text { Sphalerite II }\end{array}$ & $\begin{array}{r}11.7 \\
8.3 \\
9.1\end{array}$ & $\begin{array}{l}\text { Disseminations in Valmaseda Fm. } \\
\text { Veinlet in Valmaseda Fm. } \\
\text { Veinlet in Valmaseda Fm. }\end{array}$ \\
\hline $\begin{array}{l}\text { Altube-8 Core } \\
\text { ALT8-109.80 } \\
\text { ALT8- } 163.40 \\
\text { ALT8-231.60 } \\
\text { ALT8- } 231.60 \\
\text { ALT8-236.20 } \\
\text { ALT8-330.60 }\end{array}$ & $\begin{array}{l}\text { Pyrite } \\
\text { Pyrite } \\
\text { Sphalerite I/II } \\
\text { Pyrite } \\
\text { Pyrite } \\
\text { Pyrite }\end{array}$ & $\begin{array}{l}16.9 \\
15.7 \\
11.9 \\
21.2 \\
48.1 \\
-5.9\end{array}$ & $\begin{array}{l}\text { Disseminations in Valmaseda Fm. } \\
\text { Disseminations in Valmaseda Fm. } \\
\text { Disseminations in Valmaseda Fm. } \\
\text { Disseminations in Valmaseda Fm. } \\
\text { Disseminations in Valmaseda Fm. } \\
\text { Disseminations in CTZ }\end{array}$ \\
\hline $\begin{array}{l}\text { Altube-9 Core } \\
\text { ALT9-132.75 } \\
\text { ALT9-137.90 } \\
\text { ALT9-160.60 } \\
\text { ALT9-248.50 }\end{array}$ & $\begin{array}{l}\text { Gypsum } \\
\text { Pyrite } \\
\text { Pyrite } \\
\text { Pyrite }\end{array}$ & $\begin{array}{l}15.3 \\
-7.9 \\
13.2 \\
22.5\end{array}$ & $\begin{array}{l}\text { Keuper facies } \\
\text { Disseminations in CTZ } \\
\text { Vein in CTZ } \\
\text { Disseminations in Valmaseda Fm. }\end{array}$ \\
\hline Orduña diapir & & & \\
\hline $\begin{array}{l}\text { La Antigua } \\
\text { DO-02-03 } \\
\text { DO-02-03 } \\
\text { DO-02-06 } \\
\text { DO-02-07 }\end{array}$ & $\begin{array}{l}\text { Sphalerite I } \\
\text { Pyrite } \\
\text { Galena } \\
\text { Galena }\end{array}$ & $\begin{array}{r}10.5 \\
14.0 \\
7.3 \\
7.2\end{array}$ & $\begin{array}{l}\text { Disseminations in dolostones } \\
\text { Disseminations in dolostones } \\
\text { Vein } \\
\text { Vein }\end{array}$ \\
\hline $\begin{array}{l}\underline{\text { Montaleón }} \\
\text { DO-03-00 } \\
\text { DO-03-00 } \\
\text { DO-03-00 } \\
\text { DO-03-02 } \\
\text { DO-03-02 } \\
\text { DO-03-04 } \\
\text { DO-03-04 } \\
\text { DO-03-05 } \\
\text { DO-03-05 } \\
\text { DO-03-05 } \\
\text { DO-03-06 } \\
\text { DO-03-06 } \\
\text { DO-03-06 } \\
\text { DO-03-08 } \\
\text { DO-03-08 } \\
\text { DO-03-10 } \\
\text { DO-03-10 } \\
\text { DO-03-10 } \\
\text { DO-03-12 } \\
\text { DO-03-12 }\end{array}$ & $\begin{array}{l}\text { Galena } \\
\text { Sphalerite I } \\
\text { Pyrite } \\
\text { Galena } \\
\text { Sphalerite I } \\
\text { Sphalerite II } \\
\text { Galena } \\
\text { Galena } \\
\text { Sphalerite } \\
\text { Pyrite } \\
\text { Sphalerite I } \\
\text { Galena } \\
\text { Pyrite } \\
\text { Sphalerite I } \\
\text { Pyrite } \\
\text { Galena } \\
\text { Sphalerite } \\
\text { Sphalerite } \\
\text { Galena } \\
\text { Sphalerite }\end{array}$ & $\begin{array}{r}7.6 \\
11.2 \\
12.9 \\
6.5 \\
7.4 \\
12.4 \\
9.1 \\
7.5 \\
9.9 \\
12.9 \\
12.3 \\
9.3 \\
-2.5 \\
12.8 \\
12.8 \\
6.1 \\
9.5 \\
4.8 \\
6.6 \\
11.2\end{array}$ & $\begin{array}{l}\text { Vein } \\
\text { Vein } \\
\text { Disseminations in dolostones } \\
\text { Disseminations in dolostones } \\
\text { Disseminations in dolostones } \\
\text { Disseminations in dolostones } \\
\text { Disseminations in dolostones } \\
\text { Disseminations in dolostones } \\
\text { Disseminations in dolostones } \\
\text { Disseminations in dolostones } \\
\text { Disseminations in dolostones } \\
\text { Disseminations in dolostones } \\
\text { Disseminations in dolostones } \\
\text { Vein } \\
\text { Disseminations in Dol III } \\
\text { Disseminations in dolostones } \\
\text { Disseminations in dolostones } \\
\text { Disseminations in dolostones } \\
\text { Disseminations in dolostones } \\
\text { Disseminations in dolostones }\end{array}$ \\
\hline $\begin{array}{l}\text { Paúl } \\
\text { DO-04-01 } \\
\text { DO-04-01 } \\
\text { DO-04-01 } \\
\text { DO-04-NI } \\
\text { DO-04-NI } \\
\text { DO-04-NI }\end{array}$ & $\begin{array}{l}\text { Galena } \\
\text { Sphalerite II } \\
\text { Pyrite/Marcasite } \\
\text { Galena } \\
\text { Sphalerite I } \\
\text { Pyrite }\end{array}$ & $\begin{array}{r}8.4 \\
12.0 \\
13.7 \\
8.5 \\
10.8 \\
13.1\end{array}$ & $\begin{array}{l}\text { Semimassive sulfides } \\
\text { Semimassive sulfides } \\
\text { Semimassive sulfides } \\
\text { Disseminations in Cenomanian black shales } \\
\text { Disseminations in Cenomanian black shales } \\
\text { Disseminations in Cenomanian black shales }\end{array}$ \\
\hline $\begin{array}{l}\text { Villasana de } \mathrm{N} \\
\text { VM-02-03 } \\
\text { VM-02-03 } \\
\text { VM-02-03 }\end{array}$ & $\begin{array}{l}\text { Sphalerite } \\
\text { Sphalerite } \\
\text { Barite }\end{array}$ & $\begin{array}{r}-1.4 \\
0.2 \\
17.6\end{array}$ & $\begin{array}{l}\text { Disseminations in Valmaseda Fm. } \\
\text { Disseminations in Valmaseda Fm. } \\
\text { Disseminations in Valmaseda Fm. }\end{array}$ \\
\hline
\end{tabular}

Abbreviations: CTZ = carbonate transition zone, V-CDT = Vienna-Canyon Diablo Troilite 
Table 4. ${ }^{206} \mathrm{~Pb} /{ }^{204} \mathrm{~Pb},{ }^{207} \mathrm{~Pb} /{ }^{204} \mathrm{~Pb}$, and ${ }^{207} \mathrm{~Pb} /{ }^{204} \mathrm{~Pb}$ Ratios in Galenas

\begin{tabular}{|c|c|c|c|c|c|c|c|}
\hline Locality & Sample & ${ }^{206} \mathrm{~Pb} /{ }^{204} \mathrm{~Pb}$ & $2 \sigma(\%)$ & ${ }^{207} \mathrm{~Pb} /{ }^{204} \mathrm{~Pb}$ & $2 \sigma(\%)$ & ${ }^{208} \mathrm{~Pb} /{ }^{204} \mathrm{~Pb}$ & $2 \sigma(\%)$ \\
\hline Altube & ALT7-275.50 & 18.644 & 0.03 & 15.676 & 0.04 & 38.780 & 0.05 \\
\hline Altube & ALT2-198.30 & 18.643 & 0.03 & 15.665 & 0.04 & 38.760 & 0.05 \\
\hline Beluntza & DM-06-03 & 18.650 & 0.05 & 15.673 & 0.04 & 38.780 & 0.04 \\
\hline Jugo & DM-03-03 & 18.672 & 0.04 & 15.650 & 0.05 & 38.730 & 0.06 \\
\hline Jugo & DM-03-05 & 18.662 & 0.06 & 15.660 & 0.07 & 38.775 & 0.08 \\
\hline La Antigua & DO-02-07 & 18.696 & 0.03 & 15.661 & 0.04 & 38.750 & 0.04 \\
\hline Montaleón & DO-03-00 & 18.650 & 0.06 & 15.670 & 0.07 & 38.730 & 0.09 \\
\hline Paúl & DO-04-01 & 18.680 & 0.04 & 15.676 & 0.05 & 38.780 & 0.06 \\
\hline Paúl & DO-04-NI & 18.679 & 0.03 & 15.659 & 0.03 & 38.720 & 0.04 \\
\hline
\end{tabular}

textures and origins of organic matter can affect the evolution of physical properties (Suarez et al., 2012, and references therein). Our attempts to find possible relationships between different thermal indicators (bitumen reflectivity, fluid inclusion, and isotope geothermometry) for the anomalous samples were unsuccessful.

Regardless the enclosing rock type (siliciclastic rocks, marine carbonates, or carbonate transition zone rocks), the studied peridiapiric deposits are indistinguishable in terms of fluid salinity and temperature of formation. Temperature and depth of formation are within the range reported for MVT deposits (Wilkinson, 2001; Leach et al., 2010) and especially with other diapir-related mineralization (Posey and Kyle, 1988; Posey et al., 1994; Sheppard et al., 1996; Piqué et al., 2009; Bouhlel et al., 2016).

\section{Sulfur isotopes}

Except for some pyrite samples, $\delta^{34} \mathrm{~S}$ values of ore sulfides in Orduña and Murguía range from 4.1 to $15.1 \%$ (see Table 3; Fig. 9), pointing to a sedimentary sulfur source, either seawater sulfate or sulfate derived from the dissolution of evaporites. No significant isotopic differences between mineralization types and localities have been found, except for pyrite (see below). The $\delta^{34} \mathrm{~S}$ values of barite (16.2-24.3\%o), although higher than gypsum of upper Triassic age (Keuper facies: 15.3-17.4\%o), suggest a similar source, the heavier values corresponding to ${ }^{34} \mathrm{~S}$ enrichments after reduction of sulfate to sulfide.

Concerning the origin of $\mathrm{H}_{2} \mathrm{~S}$ for sulfide precipitation, we can envisage two situations: (1) the generation of $\mathrm{H}_{2} \mathrm{~S}$ reservoirs simultaneous with caprock development and (2) $\mathrm{H}_{2} \mathrm{~S}$ produced by ore fluid-organic matter interaction, unrelated to caprock formation. In terms of the $\delta^{34} \mathrm{~S}$ of sulfides and sulfates, the scenarios are indistinguishable.

In the first scenario, closed system evaporitic sulfate reduction (thermochemical sulfate reduction [TSR] or bacterial sulfate reduction $[\mathrm{BSR}]$ ) around the diapirs would produce dispersed $\mathrm{H}_{2} \mathrm{~S}$-rich reservoirs (sour gas) with $\delta^{34} \mathrm{~S}$ values similar to the initial sulfates $\left(\delta^{34} \mathrm{~S} \approx 16 \%\right.$ ), concomitant to caprock development. Metal-bearing basinal brines became sulfate enriched during flow along the diapiric structures. As they encountered $\mathrm{H}_{2} \mathrm{~S}$ reservoirs (chemical traps), sulfate is reduced. This process increases the $\mathrm{H}_{2} \mathrm{~S}$ concentration, generating isotopically light $\mathrm{H}_{2} \mathrm{~S}$ and triggering sulfide precipitation. The presence of small and separate sulfide occurrences in the study area would be consistent with the existence of gas traps irregularly distributed around the diapirs; however, the spatial relationship of sulfides and degassing of organic matter (see below) point to an alternative hypothesis.

In the second scenario, the sulfate-enriched brines encountered organic matter-rich rocks (e.g., Valmaseda Formation), thus inducing cracking and triggering ore precipitation. Cracking of organic matter would produce $\mathrm{H}_{2} \mathrm{~S}$ and/or $\mathrm{CH}_{4}$, starting up the thermochemical reduction of sulfate. A BSR is unlikely considering the sulfide precipitation temperatures found $\left(\sim 175^{\circ} \mathrm{C}\right.$; see thermal indicators $)$. The presence of degassing textures within the bitumen and the spatial relationship between sulfides and organic matter (see Fig. 6E, F) support this scenario. Under these conditions, the rate of sulfide precipitation is controlled by the rate of $\mathrm{H}_{2} \mathrm{~S}$ generation, a slow process during TSR but fast enough to produce small orebodies (Thom and Anderson, 2008), resulting in low nucleation and large-size crystals as observed in sphalerite (slow growth textures). Therefore, the development of the caprock would be unrelated to ore deposition, matching the general MVT deposits model (Leach et al., 2010) and the Merino and Canals (2011) model, where the $\mathrm{SO}_{4}$ contributed by the dolomitizing brine is reduced to sulfide by organic matter present in host carbonates as they are being replaced by dolomite.

At Altube, the isotopic composition of pyrite is highly variable $\left(\delta^{34} \mathrm{~S}=-41.5\right.$ to $48.1 \%$ ), although most values are close to the isotopic compositions of galena $\left(\delta^{34} \mathrm{~S}=4.1-12 \%\right)$ and sphalerite $\left(\delta^{34} \mathrm{~S}=4.6-15.1 \%\right)$. Extreme $\delta^{34} \mathrm{~S}$ values correspond to framboidal pyrite produced by BSR, unrelated to ore stages. The $\delta^{34} \mathrm{~S}$ of remaining pyrite samples depict two populations, right and left skewed with a mode around 10\%o, corresponding to disseminations within the Valmaseda Formation and the carbonate transition zone, respectively (see Table 3). This distribution is compatible with two different sulfate reduction processes: BSR related to the caprock development, thereby producing pyrite with low $\delta^{34} \mathrm{~S}$ values, and TSR related to the mineralization stage, producing pyrite with higher $\delta^{34} \mathrm{~S}$ values.

Variations of up to $8 \%$ in $\delta^{34} \mathrm{~S}$ of sulfides within a single deposit (e.g., Montaleón, Altube) could be explained by changes in $\mathrm{T}$ and/or $f_{\mathrm{O}_{2}}$ conditions during ore deposition or by the mixing of isotopically distinct sulfur sources. Considering a single source, $\delta^{34} \mathrm{~S}$ variations cannot be related either to $f_{\mathrm{O}_{2}}$ or $\mathrm{T}$ changes, since $a_{\mathrm{FeS}}$ in sphalerite is almost constant (Perona, 2016) and the $\delta^{34} \mathrm{~S}$ range of sulfides in each deposit is similar regardless of the temperature of formation. As sphalerite and galena replace host rock, including former isotopically heterogeneous pyrite, their $\delta^{34} \mathrm{~S}$ ranges could be explained as due to a mixture between the dominant evaporitic sulfur source and sulfur from ${ }^{32} \mathrm{~S}$-enriched replaced pyrite. 

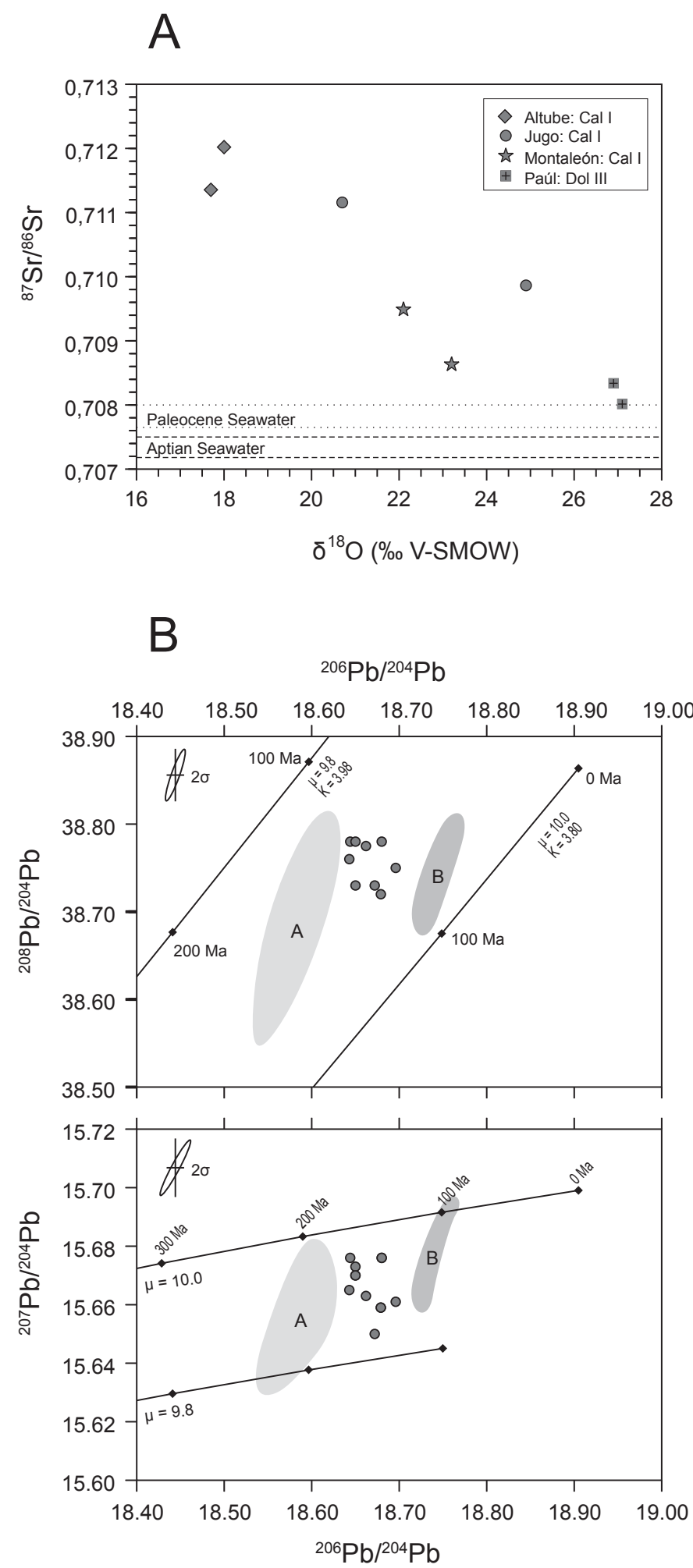

Fig. 11. (A) ${ }^{87} \mathrm{Sr} /{ }^{86} \mathrm{Sr}$ vs. $\delta^{18} \mathrm{O}$ plot of ore-stage carbonates. Strontium isotope seawater values from Burke et al. (1982). (B) Pb isotope ratios of galenas from mineralization in the Murguía and Orduña diapirs. Galenas from other MVT deposits in the Basque-Cantabrian basin have been included for comparison (Velasco et al., 1996). Group A shows Central and Eastern districts (Matienzo, Aitzgorri, Troya). Group B shows Western district (Reocín). Curves according to Stacey and Kramers (1975) Pb-growth model. Abbreviations: V-SMOW = Vienna-standard mean ocean water.
The ${ }^{34} \mathrm{~S}$ values of sulfides are similar to other MVT deposits of the Basque-Cantabrian basin (Velasco et al., 1994, 2003; Fernández-Martínez and Velasco, 1996; Piqué et al., 2009), pointing to evaporite sulfate as the main sulfur source, although most of the values are not apparently related to saline diapirs.

\section{$C, O$, and Sr isotopes in carbonates}

Most carbonates in the peridiapiric environment show $\delta^{13} \mathrm{C} / \delta^{18} \mathrm{O}$ values different from those of Mesozoic marine carbonates of the Basque-Cantabrian basin (Table 2). In a $\delta^{13} \mathrm{C} / \delta^{18} \mathrm{O}$ plot, three assemblages can be distinguished (Fig. 8): (1) samples with large $\delta^{18} \mathrm{O}$ but small $\delta^{13} \mathrm{C}$ differences (horizontal distribution; Altube, Paúl, Montaleón), (2) samples with large $\delta^{13} \mathrm{C}$ and small $\delta^{18} \mathrm{O}$ differences (vertical distribution; Aperregui, Jugo, Montaleón), and (3) samples varying from low $\delta^{13} \mathrm{C}$ and high $\delta^{18} \mathrm{O}$ to high $\delta^{13} \mathrm{C}$ and low $\delta^{18} \mathrm{O}$ (diagonal distribution; carbonate transition zone at Altube). The lowest $\delta^{13} \mathrm{C}$ values (up to $-20.5 \%$ ) are found in carbonate transition zone dolomites from Jugo, as expected for carbonates related to reduction processes of Ca sulfate in the presence of organic matter (Posey et al., 1987; Posey and Kyle, 1988; Machel et al., 1995).

Ore-stage carbonates at Altube and Montaleón show similar $\delta^{13} \mathrm{C}$ but different $\delta^{18} \mathrm{O}$ values (horizontal distribution; Fig. 8). Whereas the ${ }^{13} \mathrm{C}$ of carbonates is mainly related to the carbon source, the $\delta^{18} \mathrm{O}$ values result from changes in temperature during deposition and/or changes in the isotopic composition of the fluid. As at Altube and Montaleón, thermal indicators do not differ significantly; temperature differences alone cannot account for the distinct $\delta^{18} \mathrm{O}$ values. As already mentioned, Altube is hosted in a predominantly detrital sequence and Montaleón is hosted in carbonates, suggesting that the $\mathrm{O}$ isotope composition of hydrothermal carbonates was partially controlled by the aquifer lithology. Whereas at Montaleón the hydrothermal fluid was isotopically buffered by host marine carbonates (Turonian limestones; $\delta^{18} \mathrm{O} \sim 27 \%$ ), at Altube the interaction with the interbedded carbonate levels and carbonate diagenetic cement of the Valmaseda Formation $\left(\delta^{18} \mathrm{O} \sim 20 \%\right.$ ) produced lower $\delta^{18} \mathrm{O}$ values.

Ore-stage carbonates from Montaleón, Aperregui, and Jugo show large $\delta^{13} \mathrm{C}$ and small $\delta^{18} \mathrm{O}$ variations. The $\delta^{13} \mathrm{C}$ vertical distribution from marine to highly negative values can be explained by a progressive increase of ${ }^{12} \mathrm{C}$ in the fluid from the cracking of organic matter during sulfide precipitation and/ or by the interaction of a low-carbon hydrothermal fluid with a preexisting ${ }^{13} \mathrm{C}$-depleted caprock. The high and near-constant $\delta^{18} \mathrm{O}$ values of ore-stage carbonates would be the result of precipitation from a fluid with an oxygen isotope composition buffered by the host rock (marine and/or caprock carbonates). The presence of a carbonate-poor fluid agrees with the Merino and Canals (2011) dolomitization model, where dolomitizing brines should be $\mathrm{Mg}$ rich yet undersaturated in calcite and dolomite.

Carbonate transition zone isotope values at Altube (diagonal distribution in Fig. 8) can be explained from the interaction between the low-carbon hydrothermal fluid, the preexisting ${ }^{13} \mathrm{C}$-depleted caprock, and the carbonate cement of the Valmaseda Formation at different fluid/rock ratios. The oxygen isotope composition of precipitating carbonates (orestage calcite) would be partially buffered by the $\delta^{18} \mathrm{O}$ of the 
carbonate transition zone and that of the carbonate cement of the Valmaseda Formation. The range of carbon isotope composition would result from the interaction of the hydrothermal fluid with the $\mathrm{C}$ isotopically heterogeneous carbonate transition zone. The carbonate transition zone is made up of dolomitized breccia with carbonates from different stages (and therefore different $\delta^{13} \mathrm{C}$ values), including former true caprock fragments (see Fig. 2A), which are typically characterized elsewhere by a trend from low to very low $\delta^{13} \mathrm{C}$ and high $\delta^{18} \mathrm{O}$ values (e.g., $\delta^{13} \mathrm{C}=-14$ to $-32 \%$ and $\delta^{18} \mathrm{O}=23-26 \%$ at Damon Mound; Prikryl et al., 1988). Hence, the C/O isotope distribution of the transition zone carbonates at Altube may represent mixtures of isotopically distinct carbonate generations. The high $\delta^{18} \mathrm{O}(\sim 25 \%)$ and low $\delta^{13} \mathrm{C}(\sim-20 \%)$ values at Jugo are typical of carbonates related to reduction processes of Ca sulfate in the presence of organic matter in saline diapirs (caprock) (Posey and Kyle, 1988; Machel et al., 1995; Worden et al., 1996). This former caprock, overprinted by the low-carbon dolomitizing hydrothermal fluid related to ore deposition, discontinuously crops out around the Murguía diapir hosting mineralization at Jugo and Aperregui, among other smaller occurrences.

Ore-stage carbonates from deposits hosted in the Valmaseda Formation depict the lowest $\delta^{18} \mathrm{O}$ values and the highest ${ }^{87} \mathrm{Sr} /{ }^{86} \mathrm{Sr}$ ratios, whereas the carbonate-hosted deposits show lower ${ }^{87} \mathrm{Sr} /{ }^{86} \mathrm{Sr}$ ratios and $\delta^{18} \mathrm{O}$ values similar to those of the host rocks (Fig. 11A; Table 2). This trend is expected when oxygen and strontium isotope compositions of fluids are buffered by diagenetic cements in sandstones and marine carbonates, respectively. This negative correlation has also been reported in other MVT deposits (Fallara and Savard, 1998; Savard and Kontak, 1998), with the slope depending on the lithology of the surrounding rocks. Carbonate transition zone calcites from Altube and Jugo also plot within this trend, supporting the idea that ore fluids overprinted an existing caprock.

Carbon and $\mathrm{O}$ isotope compositions of ore-stage carbonates from MVT deposits in the Basque-Cantabrian basin depict homogeneous $\delta^{13} \mathrm{C}$ but variable $\delta^{18} \mathrm{O}$ values (Velasco et al., 1994, 2003; Piqué et al., 2009). Since the highest $\delta^{18} \mathrm{O}$ values correspond to the lowest precipitation temperatures (Reocin deposit; Grandia et al., 2003; Velasco et al., 2003) and most deposits are carbonate-hosted, $\delta^{18} \mathrm{O}$ variations cannot be only explained after lithology buffering and temperature effect are considered.

\section{$\mathrm{Pb}$ isotopes in galenas}

Lead isotope values of galenas are homogeneous and indicate a crustal source (Table 4) and plot between the two fields, Western and Central-Eastern districts, defined by Velasco et al. $(1996,2003)$ in the Basque-Cantabrian basin (Fig. 11B). According to these authors, these two fields reflect regional differences in the composition of Mesozoic-age underlying rocks derived from erosion of two different older massifs (Asturian and Sierra de la Demanda-Basque Pyrenees). Lead from peridiapiric deposits could be explained either by a mixture of $\mathrm{Pb}$ from the two sources defined by Velasco et al. (1996) or by a single source from underlying rocks having different $\mathrm{Pb}$ isotope compositions. Both hypotheses are plausible, considering the block movements that took place during the opening of the Bay of Biscay involving different types of rocks (Roca et al., 2011).

\section{Conceptual Model and Conclusions}

A combination of field and laboratory work including textural, isotopic, and organic matter analyses has provided insights into the genesis of ore deposits related to the Murguía and Orduña salt diapirs in the Basque-Cantabrian basin. The conceptual model and evolution for this type of mineralization is shown in Figure 12.

The structural evolution of the Basque-Cantabrian basin resulted in the development of tectonic lineaments with diapiric structures of Triassic rocks, which concentrated the Mesozoic extensional and the Alpine compressional deformations (Serrano and Martínez del Olmo, 2004). At Murguía, reactivation of basement faults during the Early Cretaceous induced diapirism, producing thickness changes in the siliciclastic Albian-Lower Cenomanian materials (Valmaseda Formation) (Fig. 12A). Diapiric ascent continued up to the Upper Cretaceous, as evidenced by major thickness changes in the sedimentary pile around the diapir. During the halokinesis, a caprock developed. Piercement created permeable structures, enabling the flow of basinal metal-bearing hydrothermal fluids, which produced $\mathrm{Zn}-\mathrm{Pb}$ deposits and dolomitized the caprock (carbonate transition zone). During the Campanian, reefal structures formed on top of the diapir (Fig. 12B). As the diapir reached the surface, it started to dissolve, the reefal structure collapsed, and continental sediments of lower Miocene age deposited in a small endorheic basin (LópezHorgue and Hernández, 2003; Barrón et al., 2006). The present erosion level of the Murguía diapir brought mineralization to the surface (Fig. 12C). The timing of mineral deposition cannot be constrained with precision, but halokinetic evolution of the studied diapirs suggests that ore deposits formed no later than Campanian times.

Mineralization consists of vein and stratabound sulfides (pyrite, sphalerite, and galena) with dolomite and calcite as gangue minerals, hosted by Lower Cretaceous siliciclastic sediments (Valmaseda Formation), and Upper Cretaceous carbonates and carbonates from former caprock structures (carbonate transition zone). Dolomitization and organic matter as solid bitumen are ubiquitous and spatially related to sulfide minerals.

After equilibrating with evaporite minerals (halite, anhydrite), basinal metal-bearing hydrothermal fluids became sulfate rich, increased in salinity, and attained halogen ratios compatible with halite dissolution (Grandia et al., 2003). Sulfide precipitation was triggered after sulfate reduction by organic matter present in the host rocks. The temperature attained during ore deposition $\left(150^{\circ}-200^{\circ} \mathrm{C}\right)$ suggests that TSR was the dominant sulfate reduction process. The $\delta^{34} \mathrm{~S}$ values of ore-stage pyrite, sphalerite, and galena (4.1-15.1\%o) and barite (16.2-24.3\%o) are compatible with reduction of Triassic evaporite sulfates from the diapirs (15.3-17.4\%o).

Around the diapirs, mineralizing fluids flowed through different rock types, as recorded by the $\mathrm{C}$ and $\mathrm{O}$ isotope composition of ore-stage carbonates. The $\delta^{13} \mathrm{C}$ values of ore-stage carbonates hosted in siliciclastic rocks and marine limestones ( -3 to $4 \%$ ) are close to marine carbonate values, indicating that metal-bearing basinal brines were carbon poor and 


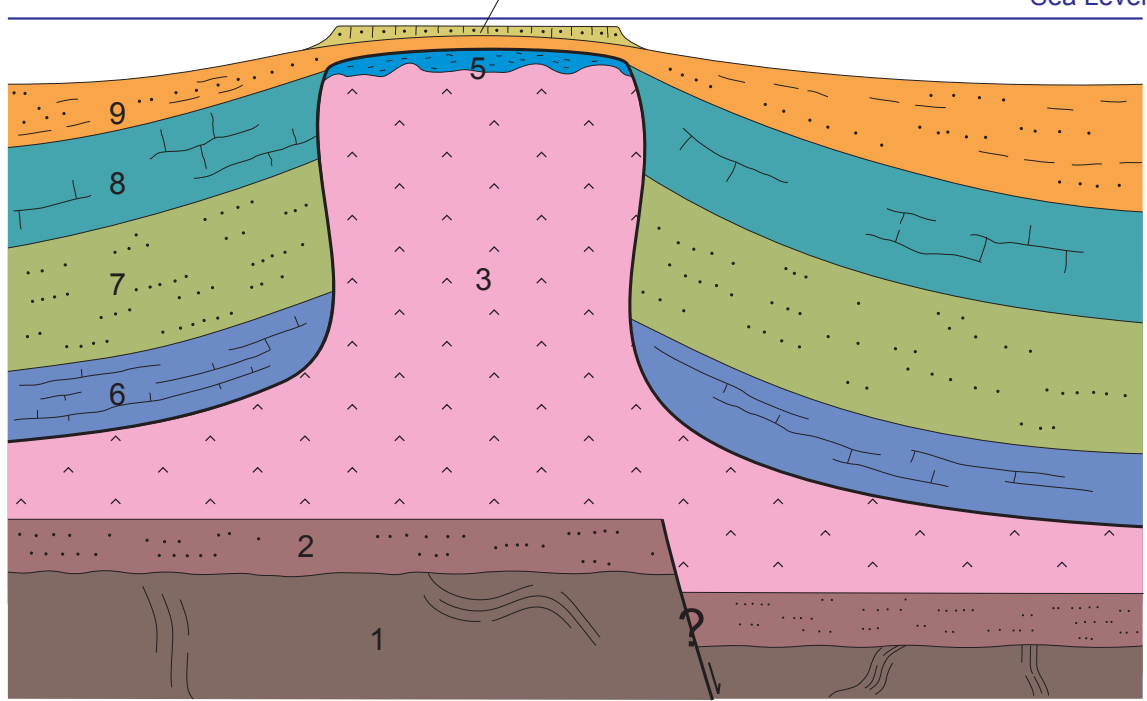

\section{B: Late Cretaceous}

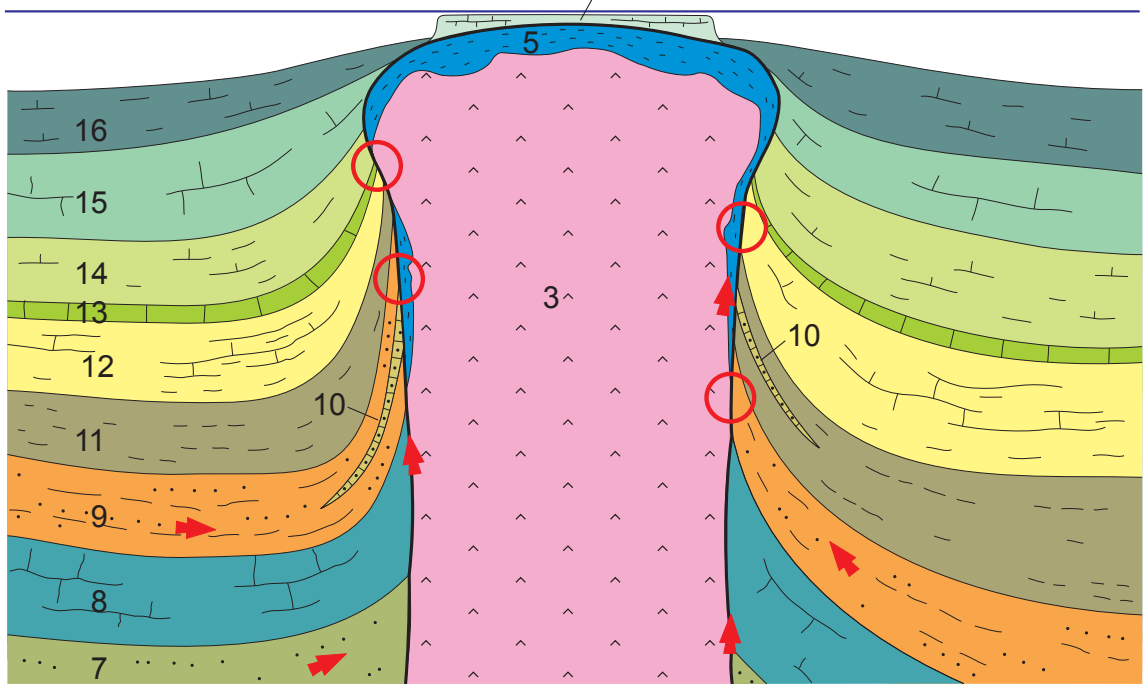

\section{C: Present}

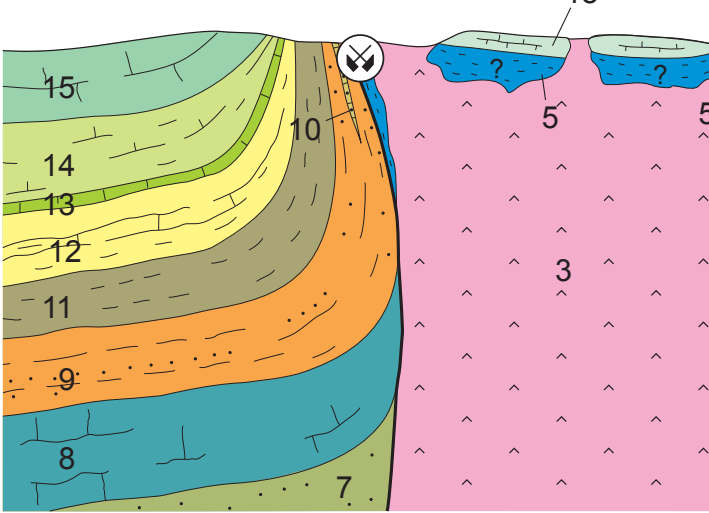

Fig. 12. Simplified evolutionary model for the Murguía diapir-related mineralization (not to scale). (A) Early Cretaceous. The diapiric movement is triggered by basement faults movements during the extensive tectonic regime. Note thinning of the Valmaseda Formation (9) toward the diapir. (B) Late Cretaceous Diapiric ascent continues up to Upper Cretaceous as evidenced by major thickness changes in the sedimentary pile around the diapir. A caprock develops during this stage (5). Permeable structures generated during piercement enable the flow of basinal metal-bearing hydrothermal fluids, which produces $\mathrm{Zn}-\mathrm{Pb}$ deposits in the surrounding rocks, including the caprock (carbonate transition zone). Reefal structures (18) form on top of the diapir. (C) Present. After salt dissolution, reefal structure collapses and erosion brings mineralization hosted in the Valmaseda Formation, Upper Cretaceous rocks, and the carbonate transition zone to the surface. Red arrows show basinal brine circulation. Red circles show $\mathrm{Zn}-\mathrm{Pb}$ mineralization. 1 = Paleozoic basement, $2=$ Early Triassic, 3 = Late Triassic (evaporites), 5 = caprock/carbonate transition zone, $6=$ Lower Jurassic. Lower Cretaceous: $7=$ Wealden, $8=$ Urgonian, $9=$ sandstones and shales (Valmaseda Formation), $10=$ reefal limestones (Valmaseda Formation), 11 = black shales (Valmaseda Formation). Upper Cretaceous: $12=$ Cenomanian rhythmic series, $13=$ Garate limestones, $14=$ Zuazo marls, $15=$ Subijana limestones, $16=$ Santonian marls and limestones, $18=$ Campanian reefal limestones. 
isotopically buffered by the enclosing rocks. The most negative $\delta^{13} \mathrm{C}$ values $(\sim-10 \%)$ of ore-stage carbonates hosted in the carbonate transition zone reflect the interaction of the hydrothermal fluid with an isotopically light $\mathrm{C}$ source as the preexisting caprock. The original isotopic composition of the caprock is preserved at the Jugo deposit, where carbonates of the carbonate transition zone show high $\delta^{18} \mathrm{O}$ values $(\sim 25 \%$ ) and $\delta^{13} \mathrm{C}$ up to $-20 \%$, typical of sulfate-reduction processes by organic matter as described in diapir-related caprock formations (e.g., Prikryl et al., 1988; Kyle and Saunders, 1996). These flow paths are also recorded by the $\delta^{18} \mathrm{O}$ values and ${ }^{87} \mathrm{Sr} /{ }^{86} \mathrm{Sr}$ ratios of ore-stage carbonates, ranging from 17 to $20 \%$ and 0.71202 when hosted in siliciclastic rocks and from 23 to $26 \%$ and 0.70801 in marine carbonates, respectively. Mineralizing fluids acquired metals from a crustal source with a $\mu$ between 9.8 and 10 , similar to other $\mathrm{Zn}-\mathrm{Pb}$ deposits of the Basque-Cantabrian basin (Velasco et al., 1996).

We have shown that peridiapiric mineralization and caprock formation at Murguía and Orduña are not related processes in terms of time and reductant sources, in contrast with that observed in the classic examples of the Gulf Coast. The studied deposits are associated with dolomitization and the presence of organic matter, sharing the main geochemical characteristics of the traditional MVT deposits and being comparable to diapir-related $\mathrm{Zn}-\mathrm{Pb}$ deposits of North Africa. In the case of the Murguía diapir, the presence of dolomitized ore-bearing remnants (carbonate transition zone) below the Upper Cretaceous and Cenozoic sedimentary rocks in the central part of the diapir cannot be ruled out. This situation contrasts with the evolution of the Orduña diapir, where the caprock has been eroded, cropping out only evaporites of Triassic age in the central part of the diapir.

\section{Acknowledgments}

The authors wish to thank J. Garcia, L. Muñoz, and A. Franco from the Ente Vasco de Energia (EVE) for supplying the drill core samples and geologic data from the Murguía and Orduña diapirs. J.R. Disnar and F. Laggoun (ISTO, Orléans, France) are thanked for assistance in generating the organic matter data. The authors would like to thank E. Roca, R. Kyle, M. Appold, the associate editor, and Editor L. Meinert for their constructive reviews and comments, which helped to improve the paper. The present work is a contribution of the Mineralogia Aplicada i Geoquímica de Fluids 2014SGR-1456 and 2017SGR-1733 Research Group.

\section{REFERENCES}

Ábalos, B., Alonso, N., Berrocal, T., Furundarena, A., Gorospe, I., Martínez-Escauriaza, G., Matxain, I., and Sánchez-Lorda, M.E., 2003, Análisis estructural de los surcos periféricos del diapiro de Murguía (Álava, Cuenca Vasco-Cantábrica): Geogaceta, v. 34, p. 7-10.

Baquedano, K., 2007, La búsqueda de petróleo en Álava: Donostia, Eusko Ikaskuntza, $111 \mathrm{p}$.

Barker, C.E., and Pawlewicz, M.J., 1994, Calculation of vitrinite reflectance from thermal histories and peak temperatures: American Chemical Society (ACS) Symposium Series, v. 570, p. 216-229.

Barrón, E., Hernández, J.M., López-Horgue, M.A., and Alcalde-Olivares, C., 2006, Palaeoecology, biostratigraphy, and palaeoclimatology of the lacustrine fossiliferous beds of the Izarra Formation (lower Miocene, Basque-Cantabrian basin, Alava Province, Spain) based on palynological analysis: Revista Española de Micropaleontología, v. 38, p. 321-338.

Bouhlel, S., Leach, D.L., Johnson, C.A., Marsh, E., Salmi-Laouar, S., and Banks, D.A., 2016, A salt diapir-related Mississippi Valley-type deposit: The
Bou Jaber Pb-Zn-Ba-F deposit, Tunisia: Fluid inclusion and isotope study: Mineralium Deposita, doi: 10.1007/s00126-015-0634-8.

Burke, W.H., Denison, R.E., Hetherington, E.A., Koepnick, R.B., Nelson, H.F., and Otto, J.B., 1982, Variation of seawater ${ }^{87} \mathrm{Sr} / 86 \mathrm{Sr}$ throughout Phanerozoic time: Geology, v. 10, p. 516-519.

Bustillo, M., and Ordóñez, S., 1995, Lower Cretaceous Pb-Zn ores of Cantabria, northern Spain: New considerations based on petrological and geochemical evidence: Transactions of the Institution of Mining and Metallurgy: Section B: Applied Earth Science, v. 104, p. 55-65.

Cámara, P., 1997, The Basque-Cantabrian basin's Mesozoic tectono-sedimentary evolution: Mémoires du Societé Géologique de France, v. 171, p. 187-191.

Castañares, L.M., Robles, S., Gimeno, D., and Vicente Bravo, J.M., 2001, The submarine volcanic system of the Errigoiti Formation (Albian-Santonian of the Basque-Cantabrian basin, northern Spain): Stratigraphic framework, facies, and sequences: Journal of Sedimentary Research, v. 71-2, p. 318-333.

Czamanske, G.K., and Rye, R.O., 1974, Experimentally determined sulfur isotope fractionations between sphalerite and galena in the temperature range 600 degrees to 275 degrees C: Economic Geology, v. 69, p. 17-25.

Ente Vasco de la Energia (EVE), 1994, Mapa Geológico del País VascoEuskal Herriko Mapa Geologikoa, escala 1:100,000.

Evans, D.G., Nunn, J.A., and Hanor, J.S., 1991, Mechanisms driving groundwater flow near salt domes: Geophysical Research Letters, v. 18, no. 5 , p. 927-930.

Fallara, F., and Savard, M.M., 1998, A structural, petrographic, and geochemical study of the Jubilee $\mathrm{Zn}-\mathrm{Pb}$ deposit, Nova Scotia, Canada, and a new metallogenic model: Economic Geology, v. 93, p. 757-778.

Fernández-Martínez, J., and Velasco, F., 1996, The Troya Zn-Pb carbonate-hosted SEDEX deposit, northern Spain: Society of Economic Geologists Special Publication 4, p. 364-377.

Fink, R., Virgo, S., Arndt, M., Visser, W., Littke, R., and Urai, J.L., 2016, Solid bitumen in calcite veins from the Natih Formation in the Oman Mountains: Multiple phases of petroleum migration in a changing stress field: International Journal of Coal Geology, v. 157, p. 39-51.

Frankovic, A., Eguiluz, L., and Martínez-Torres, L.M., 2016, Geodynamic evolution of the Salinas de Añana diapir in the Basque-Cantabrian basin, western Pyrenees: Journal of Structural Geology, v. 83, p. 13-27.

García-Mondéjar, J., Agirrezabala, L.M., Aramburu, A., Fernández-Mendiola, P.A., Gómez-Pérez, I., López-Horgue, M., and Rosales, I., 1996 , Aptian-Albian tectonic pattern of the Basque-Cantabrian basin (northern Spain): Geological Journal, v. 31, p. 13-45.

García-Mondéjar, J., López-Horgue, M.A., Aranburu, A., and FernándezMendiola, P.A., 2005, Pulsating subsidence during a rift episode: Stratigraphic and tectonic consequences (Aptian-Albian, northern Spain): Terra Nova, v. 17, p. $517-525$

García-Ruíz, J.M., and Otálora F., 2015, Crystal growth in geology: Patterns on the rocks, in Nishinaga, T., and Rudolph, P., eds., Handbook of crystal growth, vol. 2: New York, Elsevier, p. 1-43.

Gómez, M., Vergés, J., and Riaza, C., 2002, Inversion tectonics of the northern margin of the Basque-Cantabrian basin: Bulletin de la Societé Géologique de France, v. 173, p. 449-459.

Grandia, F., Canals, A., Cardellach, E., Banks, D.A., and Perona, J., 2003, Origin of ore-forming brines in sediment-hosted $\mathrm{Zn}$ - $\mathrm{Pb}$ deposits of the BasqueCantabrian basin, northern Spain: Economic Geology, v. 98, p. 1397-1411.

Grunau, H.R., 1987, A worldwide look at the caprock problem: Journal of Petroleum Geology, v. 10, p. 245-266.

Harding, R., and Huuse, M., 2015, Salt on the move: Multistage evolution of salt diapirs in the Netherlands North Sea: Marine and Petroleum Geology, v. 61, p. $39-55$

Henry, D.J., and Guidotti, C.V., 1985, Tourmaline as a petrogenetic indicator mineral: An example from the staurolite-grade metapelites of NW Maine: American Mineralogist, v. 70, p. 1-15.

Henry, D.J., Sun, H., Slack, J.F., and Dutrow, B.L., 2008, Tourmaline in metaevaporites and highly magnesian rocks: Perspectives from Namibian tourmalinites: European Journal of Mineralogy, v. 20, p. 889-904.

International Committee for Coal Petrology (ICCP), 1963, International handbook of coal petrography, 2nd ed.: Paris, National Center for Scientific Research (CNRS).

Jackson, C.A.L., and Lewis, M.M., 2012, Origin of an anhydrite sheath encircling a salt diapir and implications for the seismic imaging of steep-sided salt structures, Egersund basin, northern North Sea: Journal of the Geological Society of London, v. 169, p. 593-599. 
Jenkyns, H.C., 1980, Cretaceous anoxic events: From continents to oceans: Journal of the Geological Society of London, v. 137, p. 171-188.

Kyle, J.R., and Posey, H.H., 1991, Halokinesis, cap rock development, and salt dome mineral resources, in Melvin, J.L., ed., Evaporites, petroleum, and mineral resources: New York, Elsevier, p. 413-474.

Kyle, J.R., and Price, P.E., 1986, Metallic sulphide mineralization in saltdome caprocks, Gulf Coast, U.S.A.: Transactions of Institution of Mining and Metallurgy, Section B, v. 95, p. B6-B16.

Kyle, J.R., and Saunders, J.A., 1996, Metallic deposits of the Gulf Coast basin, diverse mineralization styles in a young sedimentary basin: Society of Economic Geologists Special Publication 4, p. 218-229.

Lafargue, E., Espitalié, J., Marquis, F., and Pillot, D., 1998, Rock-Eval 6 applications in hydrocarbon exploration, production, and in soil contamination studies: Revue de l'Institut Français du Pétrole, v. 53, p. 421-437.

Leach, D.L., 2014, Evaporites and Mississippi Valley-type Zn-Pb-Ag deposits: An evolving perspective: Acta Geologica Sinica (English Edition), v. 88, supp. 2, p. 174-175.

Leach, D.L., Bradley, D.C., Huston, D., Pisarevsky, S.A., Taylor, R.D., and Gardoll, S.J., 2010, Sediment-hosted lead-zinc deposits in Earth history: Economic Geology, v. 105, p. 593-625.

Leach, D.L., Song, Y.C., and Hou, Z.Q., 2017, The world-class Jinding Zn-Pb deposit: Ore formation in an evaporite dome, Lanping basin, Yunnan, China: Mineralium Deposita, v. 52, p. 281-296, doi: 10.1007/s00126-016-0668-6.

López-Horgue, M.A., and Hernández, J.M., 2003, La cuenca terciaria continental del Diapiro de Murguía: la Formación Izarra (Oligoceno superiorMioceno inferior, Cuenca Vasco-Cantábrica): Geogaceta, v. 33, p. 123-126.

Machel, H.G., Krouse, H.R., and Sassen, R., 1995, Products and distinguishing criteria of bacterial and isotopic ratios in low-concentration natural samples: Applied Geochemistry, v. 10, p. 373-389.

Martín-Chivelet, J., Berástegui, X., Rosales, I., Vilas, L., Vera, J.A., Caus, E., Gräfe, K-U., Mas, R., Puig, C., Segura, M., Robles, S., Floquet, M., Quesada, S., Ruiz-Ortiz, P., Fregenal-Martínez, M.A., Salas, R., Arias, C., García, A., Martín-Algarra, A., Meléndez, M.N., Chacón, B., Molina, J.M., Sanz, J.L., Castro, J.M., García-Hernández, M., Carenas, B., García-Hidalgo, J., Gil, J., and Ortega, F., 2002, Chapter 12: Cretaceous, in Gibbons, W., and Montero, M.T., eds., The geology of Spain: London, Geological Society, p. 255-292.

Merino, E., and Canals, A., 2011, Self-accelerating dolomite-for-calcite replacement: Self-organized dynamics of burial dolomitization and associated mineralization: American Journal of Science, v. 311, p. 573-607.

Nettleton, L.L., 1968, Gravity anomalies over salt diapirs, northern Spain: Geological Society of America Special Papers, v. 88, p. 75-82.

Pérez García, A., Robles, S., and Vicente Bravo, J.C., 1997, Arquitectura estratigráfica del sistema de plataforma dominada por tormentas de la Fm. Valmaseda (Albiense superior-Cenomaniense inferior de la cuenca Vascocantábrica): Geogaceta, v. 22, p. 153-156.

Perona, J., 2016, Mineralizaciones asociadas a los diapiros de Murguía y Orduña (Cuenca Vasco-Cantábrica): Ph.D. thesis, Bellaterra, Spain, Universitat Autònoma de Barcelona, 271 p.

Piqué, À., Canals, À., Disnar, J.R., and Grandia, F., 2009, In situ thermochemical sulfate reduction during ore formation at the Itxaspe $\mathrm{Zn}-(\mathrm{Pb})$ MVT occurrence (Basque-Cantabrian basin, northern Spain): Geologica Acta, v. 7, p. 431-449.

Posey, H.H., and Kyle, J.R., 1988, Fluid-rock interactions in the salt dome environment: An introduction and review: Chemical Geology, v. 74, p. 1-24.

Posey, H.H., Kyle, J.R., Jackson, T.J., Hurst, S.D., and Price, P.E., 1987, Multiple fluid components of salt diapirs and salt dome cap rocks, Gulf Coast, U.S.A: Applied Geochemistry, v. 2, p. 523-534.

Posey, H.H., Kyle, J.R., and Agee, W.N., 1994, Relations between diapiric salt structures and metal concentrations, Gulf Coast sedimentary basin, southern North America: Society of Geology Applied to Mineral Deposits, Special Publication 10, p. 139-164.

Prikryl, J.D., Posey, H.H., and Kyle, J.R., 1988, A petrographic and geochemical model for the origin of calcite cap rock at Damon Mound salt dome, Texas, U.S.A.: Chemical Geology, v. 74, p. 67-97.

Rat, P., 1959, Les pays crétacés basco-cantabriques (Espagne): Paris, Presses universitaires de France, $522 \mathrm{p}$.

1988, The Basque-Cantabrian basin between the Iberian and European plates; some facts but still many problems: Revista de la Sociedad Geológica de España, v. 1, no. 3-4, p. 327-348.
Roca, E., Muñoz, J.A., Ferrer, O., and Ellouz, N., 2011, The role of the Bay of Biscay Mesozoic extensional structure in the configuration of the Pyrenean orogen: Constraints from the MARCONI deep seismic reflection survey: Tectonics, v. 30, no. 2, doi: 10.1029/2010TC002680.

Rouvier, H., Perthuisot, V., and Mansouri, A., 1985, Pb-Zn deposits and salt-bearing diapirs in southern Europe and North Africa: Economic Geology, v. 80, p. 666-687.

Salas, R., Guimerà, J., Mas, R., Martín-Closas, C., Meléndez, A., and Alonso, A., 2001, Evolution of the Mesozoic central Iberian rift system and its Cainozoic inversion (Iberian chain: Mémoires du Muséum National d'Histoire Naturelle, v. 186, p. 145-186.

Savard, M.M., and Kontak, D.J., $1998, \delta^{13} \mathrm{C}-\delta^{18} \mathrm{O}-{ }^{87} \mathrm{Sr} /{ }^{86} \mathrm{Sr}$ covariations in ore-stage calcites at and around the Gays River Pb-Zn deposit (Nova Scotia, Canada); evidence for fluid mixing: Economic Geology, v. 93, p. 818-833.

Schoenherr, J., Littke, R., Urai, J.L., Kukla, P.A., and Rawahi, Z., 2007, Polyphase thermal evolution in the Infra-Cambrian Ara Group (South Oman salt basin) as deduced by maturity of solid reservoir bitumen: Organic Geochemistry, v. 38, p. 1293-1318.

Serrano, A., and Martínez del Olmo, W., 1990, Tectónica salina en el Dominio Cántabro-Navarro: Evolución, edad y origen de las estructuras salinas, in Ortí, F., and Salvany, J.M., eds., Formaciones evaporíticas de la Cuenca del Ebro y cadenas periféricas, y de la zona de Levante: Barcelona, ENRESA y GPPG, p. 39-53.

2004, Estructuras diapíricas de la zona meridional de la Cuenca VascoCantábrica, in Vera, J.A., ed., Geología de España: Madrid, SGE-IGME, p. 334-338.

Serrano, A., Martínez del Olmo, W., and Cámara, P., 1989, Diapirismo del Trías salino en el dominio Cántabro-Navarro, Libro homenaje a Rafael Soler: Madrid, Asociación de Geólogos y Geofísicos Españoles del Petróleo, p. 115-121.

Sheppard, S.M.F., Charef, A., and Bouhlel, S., 1996, Diapirs and Zn-Pb mineralization: A general model based on Tunisian (N. Africa) and Gulf Coast (U.S.A.) deposits: Society of Economic Geologists Special Publication 4, p. 230-243.

Suárez-Ruiz, I., Flores, D., Mendonça Filho, J.G., and Hackley, P.C., 2012, Review and update of the applications of organic petrology; Part 2, geological and multidisciplinary applications: International Journal of Coal Geology, v. 98, p. 73-94.

Stacey, J.S., and Kramers, J.D., 1975, Approximation of terrestrial lead isotope evolution by a two-stage model: Earth and Planetary Science Letters, v. 26 , p. $207-221$.

Taviani, S., and Muñoz, J.A., 2012, Mesozoic rifting in the Basque-Cantabrian basin (Spain): Inherited faults, transversal structures, and stress perturbation: Terra Nova, v. 24, p. 70-76.

Thom, J., and Anderson, G.M., 2008, The role of thermochemical sulfate reduction in the origin of Mississippi Valley-type deposits. I. Experimental results: Geofluids, v. 8, p. 16-26.

Velasco, F., Herrero, J.M., Gil, P.P., Álvarez, L., and Yusta, I., 1994, Mississippi Valley-type, Sedex, and iron deposits in Lower Cretaceous rocks of the Basque-Cantabrian basin, northern Spain: Society of Geology Applied to Mineral Deposits, Special Publication 10, p. 354-389.

Velasco, F., Pesquera, A., and Herrero, J.M., 1996, Lead isotope study of $\mathrm{Zn}-\mathrm{Pb}$ ore deposits associated with the Basque-Cantabrian basin and Paleozoic basement, northern Spain: Mineralium Deposita, v. 31, p. 84-92.

Velasco, F., Herrero, J.M., Yusta, I., Alonso, J.A., Seebold, I., and Leach, D., 2003, Geology and geochemistry of the Reocín zinc-lead deposit, BasqueCantabrian basin, northern Spain: Economic Geology, v. 98, p. 1371-1396.

Vergés, J., and García-Senz, J., 2001, Mesozoic evolution and Cainozoic inversion of the Pyrenean rift: Mémoires du Muséum National d'Histoire Naturelle, v. 186, p. 187-212.

Wilkinson, J.J., 2001, Fluid inclusions in hydrothermal ore deposits: Lithos, v. 55 , p. $229-272$.

Wilson, P.A., and Norris, R.D., 2001, Warm tropical ocean surface and global anoxia during the mid-Cretaceous period: Nature, v. 412, p. 425-429.

Worden, R.H., Smalley, P.C., and Oxtoby, N.H., 1996, The effects of thermochemical sulfate reduction upon formation water salinity and oxygen isotopes in carbonate gas reservoirs: Geochimica et Cosmochimica Acta, v. 60 , p. $3925-3931$.

U.S. Energy Information Administration, 2015, Technically recoverable shale oil and shale gas resources: Spain: Independent Statistics and Analysis, www.eia.gov/analysis/studies/worldshalegas/pdf/Spain_2013.pdf. 
Joaquim Perona obtained a degree in geology at the Universitat de Barcelona (UB), Spain, and a $\mathrm{Ph} . \mathrm{D}$. degree in ore deposits at the Universitat Autònoma de Barcelona, Spain. Since 2004 he has been working at the Scientific and Technological Center of the UB as a stable isotope analyst.

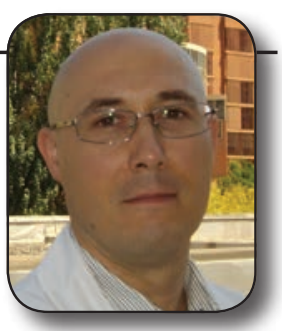


